\title{
Mass tracking for chemical analysis: the causes of ozone formation in southern Ontario during BAQS-Met 2007
}

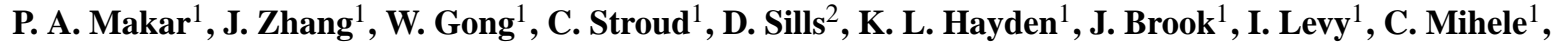 \\ M. D. Moran ${ }^{1}$, D. W. Tarasick ${ }^{1}$, H. He ${ }^{1}$, and D. Plummer ${ }^{3}$ \\ ${ }^{1}$ Air Quality Research Division, Science and Technology Branch, Environment Canada, 4905 Dufferin Street, Toronto, \\ Ontario, Canada \\ ${ }^{2}$ Cloud Physics and Severe Weather Research Section, Environment Canada, 4905 Dufferin Street, Toronto, Ontario, Canada \\ ${ }^{3}$ Climate Research Division, Science and Technology Branch, Environment Canada, Montreal, Quebec, Canada
}

Received: 28 April 2010 - Published in Atmos. Chem. Phys. Discuss.: 9 June 2010

Revised: 1 November 2010 - Accepted: 3 November 2010 - Published: 26 November 2010

\begin{abstract}
A three-level nested regional air pollution model has been used to study the processes leading to high ozone concentrations in the southern Great Lakes region of North America. The highest resolution simulations show that complex interactions between the lake-breeze circulation and the synoptic flow lead to significant enhancements in the photochemical production and transport of ozone at the local scale. Mass tracking of individual model processes show that Lakes Erie and St. Clair frequently act as photochemical ozone production regions, with average mid-day production rates of up to 3 ppbv per hour. Enhanced ozone levels are evident over these two lakes in 23-day-average surface ozone fields. Analysis of other model fields and aircraft measurements suggests that vertical circulation enhances ozone levels at altitudes up to $1500 \mathrm{~m}$ over Lake St. Clair, whereas subsidence enhances ozone over Lake Erie in a shallow layer only $250 \mathrm{~m}$ deep. Mass tracking of model transport shows that lake-breeze surface convergence zones combined with the synoptic flow can then carry ozone and its precursors hundreds of kilometers from these source areas, in narrow, elongated features. Comparison with surface mesonet ozone observations confirm the presence, magnitude, and timing of these features, which can create local ozone enhancements on the order of $30 \mathrm{ppbv}$ above the regional ozone levels. Sensitivity analyses of model-predicted ozone and $\mathrm{HO}_{\mathrm{x}}$ concentrations show that most of the region is VOC-limited, and that the secondary oxidation pathways of aromatic hydrocarbons have a key role in setting the region's ozone and $\mathrm{HO}_{\mathrm{x}}$ levels.
\end{abstract}

Correspondence to: P. A. Makar (paul.makar@ec.gc.ca)

\section{Introduction}

The local and mesoscale circulations that arise from contrasts in the heat capacity of land versus water can have a significant effect on air pollution. At the shorelines of large bodies of water (oceans, large lakes), a diurnally-varying circulation frequently develops during the warm season. Air over the land is warmed after sunrise and mixed vertically whereas the air over the water is warmed much less, resulting in local pressure differences at some distance above the surface. These pressure differences drive a local circulation during the day, with above-surface air flowing from land to water. This in turn induces daytime divergence at the surface over the water, surface convergence over the land, with a return on-shore circulation at the surface. The reverse occurs at night. The daytime surface divergence and associated water-to-land wind flow is known as the lake- or sea-breeze, while the reverse circulation is referred to as the land breeze (cf. Atkinson, 1981; Stull, 1988). The leading edge of the intrusion of marine air onto land may sometimes create a sharp gradient in temperature, wind speed, relative humidity and atmospheric stability; a lake (or sea) breeze front. Air-lake temperature contrasts less than $12^{\circ} \mathrm{C}$ are sufficient to induce this circulation (Laird et al., 2001). In light winds, temperature contrasts of only a few degrees are sufficient to induce the circulation - as synoptic wind speeds increase, larger contrasts are required.

Non-reactive tracer modelling studies of coastal Los Angeles noted the ability of sea-breeze-induced fronts (sometimes coupled with topographic effects) to provide sufficient vertical transport to loft pollutants to high levels during the day, in turn creating elevated layers of high concentration

Published by Copernicus Publications on behalf of the European Geosciences Union. 
pollutants with the onset of more stable conditions at night (Lu and Turco, 1995). Similar layering structures have been observed in numerous measurement studies in coastal environments (cf. Li, 2004). The sea or lake breeze is often weak with respect to the synoptic flow, but combinations of the two have frequently been shown to give rise to increased pollution levels, including Taiwan in the autumn (Cheng, 2002), Houston (Banta et al., 2005), Vancouver (Li, 2004), Marseille (Mestayer et al., 2005; Lasry et al., 2005), and Madrid and Valencia (Millán et al., 1997, 2000).

Houston is sometimes severely affected by sea-breezeenhanced ozone levels. Analyses of surface winds, upperlevel synoptic maps, and meteorological conditions have shown that the highest ozone days in that city are associated with the passage of sea-breeze fronts (Darby, 2005; Rappenglück et al., 2008). Cluster analysis of surface winds showed that these events correspond to the situation wherein the transition from offshore to onshore flow is separated by a period of stagnation greater than or equal to one hour, up to six hours before the ozone event (Darby, 2005). The timing of the arrival of the sea-breeze front is the key factor in predicting high-pollution events in Houston, and sea breezes in opposition to the synoptic flow lead to the highest pollution, due to recirculation of processed air (Banta et al., 2005). The depth of penetration of sea-breeze fronts onto land is dependant on the direction of the synoptic wind, as well as on the local radiative balance and land-surface characteristics (Cheng and Byun, 2008), and these factors in turn have a more significant effect on ozone forecasts than, for example, the choice of plume-rise parameterization in an air-quality model (Cheng et al., 2008). The placement of major emissions sources relative to regularly repeating sea-breeze locations also has a significant impact on both ozone formation and dilution in the Greater Houston area (Byun et al., 2007).

The city of Marseille has been another focus for seabreeze-induced meteorological and air pollution studies. High-resolution modelling studies have suggested that sea and lake breezes interact with Marseille's VOC emissions to create high ozone episodes (Lasry et al., 2005). Sophisticated urban heat island modelling for the same region suggests that Marseille's urban heat island circulation is affected by the sea breeze: the urban circulation when the city was affected by sea breezes was suppressed relative to instances of synoptic flows originating over the land (Lemonsu et al., 2006a; Drobinski et al., 2007). Work by the same group (Lemonsu et al., 2006b) also suggested the presence of "deep" and "shallow" sea-breeze circulations, the former inhibited by topography, the latter enhanced by topography. Relatively low $\mathrm{NO}_{2}$ and high $\mathrm{O}_{3}$ in the Marseille marine boundary layer (indicative of a more photochemically aged airmass) suggest that the sea-breeze circulation acts as an efficient photochemical reactor (Puygrenier et al., 2005). Pollutant concentrations in Marseille are highest just upwind of the sea-breeze front (the front's propagation speed is lower than the wind speed, and the vertical mass flux at the front is less than the horizontal flux within the sea-breeze, allowing pollutants to accumulate just behind the front, with some upward transport; (Drobinski et al., 2007). The accurate simulation of the fine-scale features of sea-breeze mesoscale transport in the Marseille area is crucial in order to predict both ozone peaks and ozone plumes (Pirovano et al., 2007).

The surface temperature during the passage of Marseille's sea-breeze front has been found to be oscillatory (Puygrenier et al., 2005; Drobinski et al., 2007). Cold air transported inland due to the sea breeze results in temporarily increased stability over the land (isentrope inclination allows the seabreeze flow to run along the slope, and adiabatic cooling associated with rising air retards the flow). The stability is short-lived, as solar energy is transferred to the surface, triggering turbulent vertical transport, including convection. The upward motion results in surface-level convergence over the land - this in turn amplifies the sea-breeze flow, which in turn advects cooler air over the land, increasing stability again, and slowing forward motion until the cycle repeats. Recent attempts to model this observed oscillatory flow have been unsuccessful (Drobinski et al., 2007).

The two main mechanisms for venting Marseille's boundary-layer air to the free troposphere are upslope winds enhanced by sea breezes, and frontogenesis at the sea-breeze front, with associated turbulence and upward motion (Bastin and Drobinksi, 2006). This venting is of sufficient magnitude to prevent significant recirculation of aged air back into the PBL (Drobinski et al., 2007).

Recirculation of aged polluted air in sea-breeze fronts has been observed elsewhere, however. Along the New England coastline, recirculation of aged air in sea-breeze fronts has been observed to increase ozone concentrations by 10 to 30 ppbv (Darby et al., 2007). The same study showed the presence of ozone aloft available for downward transport in frontal circulation along with recirculation patterns along the coast, but the observational evidence was not always sufficient to determine the cause of high ozone events (e.g., three possible sources for an event on 4 August 2004). Recirculation also has a significant impact on pollutant concentrations along the eastern Mediterranean (Levy et al., 2008). As in the Marseille studies, the interaction between synoptic and mesoscale flows was found to govern the impact of the sea breeze on air pollution. The presence of urban heat islands and the shape of the coastline modified the sea breeze, with the former reducing sea-breeze intensity, and the latter creating convergence regions that intensified it. The mechanism for sea-breeze impacts on eastern Mediterranean ozone levels is unclear, with high ozone levels occurring for both high and low recirculation, and an anti-correlation with $\mathrm{NO}_{\mathrm{x}}$, suggesting both local and long-range transport sources of ozone.

Observational studies of lake-breeze fronts and their impacts on air pollution in the region of the Great Lakes of North America began in the 1960's (Mukammal, 1965; Lyons and Cole, 1973, 1976; Lyons and Olsson, 1973; Anlauf et al., 1975). Model simulations of the air pollution 
associated with lake-breeze circulations started with simple Gaussian dispersion models of non-reactive tracers, but the limitations of these models (Lyons et al., 1983) led to the use of full mesoscale models at resolutions of 1 to $10 \mathrm{~km}$ as the drivers for non-reactive tracer dispersion studies (Lyons et al., 1995). The lake-breeze circulation was found to be considerably more complex than previously expected: simulated non-reactive tracer plumes released at the shoreline were entirely transported out of the shallow lake-breeze inflow layer upon reaching the lake-breeze front and tracer plumes followed helical and even bifurcating trajectories (Lyons et al., 1995).

The reactive ozone chemistry associated with lake-breeze fronts in southern Ontario was first examined in the 1980's and 1990's. Some of this early work (e.g., Yap et al., 1988) suggested that local impacts on ozone levels were generally small, while some noted a more significant impact (Mukammal et al., 1982, 1985). Ozone concentration increases of $30 \mathrm{ppbv}$ over the course of a few minutes were linked through surface station and satellite observations to the passage of a lake-breeze front in a later, more detailed analysis (Hastie et al., 1999). Time-coincident aircraft measurements of precursor $\mathrm{NO}_{\mathrm{x}}$ and VOCs suggested that the air mass associated with the ozone maximum was well-aged and had moved inland from a position originating over Lake Ontario.

A common feature of the work to date on lake- or seabreeze fronts is their complex nature; they are very localscale features which nevertheless may have a profound impact on surface ozone concentrations in polluted regions. Three-dimensional mesoscale meteorological and air-quality models have provided a useful means of analyzing that complexity in Los Angeles, Houston, Taiwan and Marseille. In the study that follows, we use nested meteorological and airquality models to analyze ozone formation in lake-breeze fronts in southern Ontario, a region surrounded by four large lakes, for a field study conducted during summer 2007. As part of that analysis, we use the concept of mass- or operatortracking, in which the changes to a pollutant's concentration (in this case, ozone) are tracked through every numerical operator of the air-quality model, allowing us to quantify the relative importance of different processes towards ozone formation in the study region.

The Border Air-Quality Study and Meteorology Study (BAQS-Met) was conducted in the region between Lakes Huron, St. Clair, and Erie, with the aim of studying the impact of lake breezes on local air-quality and long-rangetransported chemistry. The study comprised a measurementintensive field campaign from 20 June to 10 July 2007, as well as a local monitoring network that operated from the months of June through August. A variety of measurements for particulate matter (PM) and gases were carried out at three supersites (Bear Creek, Harrow, and Ridgetown), on board the National Research Council of Canada (NRC) Twin Otter aircraft, and on Environment Canada's CRUISER mobile laboratory as part of the study. A ten-site mesonet mon- itoring network for 5-min average ozone and $\mathrm{PM}_{2.5}$ was installed in the study region, in addition to ozone and $\mathrm{PM}_{2.5} \mathrm{ob}-$ servations available from larger-scale monitoring networks (AIRNow).

The work that follows has two main components. First, following a discussion of our methodology (Sect. 2), we present a formal statistical evaluation of the model using the available BAQS-Met data set (Sect. 3). Second, we make use of the model output to infer the physical and chemical causes for ozone formation in the region, using time sequences of model concentration fields, process mass tracking, and comparison of model and observed ozone time series (Sect. 4). The implications of the analysis and concluding remarks are presented in Sect. 5.

\section{Methodology}

\subsection{Modelling system description}

AURAMS (A Unified Regional Air-quality Modelling System) consists of three main components: (a) a prognostic meteorological model, GEM (Global Environmental Multiscale model: Côté et al., 1998); (b) an emissions processing system, SMOKE (Sparse Matrix Operator Kernel Emissions: Houyoux et al., 2000; CEP, 2003); and (c) an off-line regional chemical transport model, the AURAMS Chemical Transport Model (CTM: cf. Cho et al., 2009; Gong et al., 2006; Makar et al.; 2009; Smyth et al., 2009; Stroud et al., 2008).

GEM version 3.2.2 with physics version 4.5 was run on two domains: a variable-resolution global horizontal grid with a uniform core domain covering North America $(575 \times 641$ grid points over the globe, with $432 \times 565$ grid points over North America, $0.1375^{\circ}$ or approximately 15.3 $\mathrm{km}$ grid spacing in the core region, 450-s timestep), and a limited-area mesoscale domain covering the Great Lakes area $\left(565 \times 494\right.$ grid points, $0.0225^{\circ}$ or approximately 2.5 $\mathrm{km}$ grid spacing, 60-s timestep). The model employed 58 hybrid-coordinate levels from the Earth's surface to $10 \mathrm{hPa}$, with layer thickness increasing monotonically with height (the first three levels above the surface, relative to standard pressure at sea level are at 42,126 , and $225 \mathrm{~m}$ ). The coarse-resolution domain was driven by the operational objective analysis and coarse-grid output was used to provide lateral boundary conditions for the high-resolution domain meteorological simulations (Fig. 1). The standard version of GEM 3.2.2 was modified to include a parameterization for urban heating (Makar et al., 2006). Additional improvements included a temperature-gradient-based boundary-layer height parameterization, and consistency improvements for the model-generated vertical diffusion coefficients in the lowest model layers. 


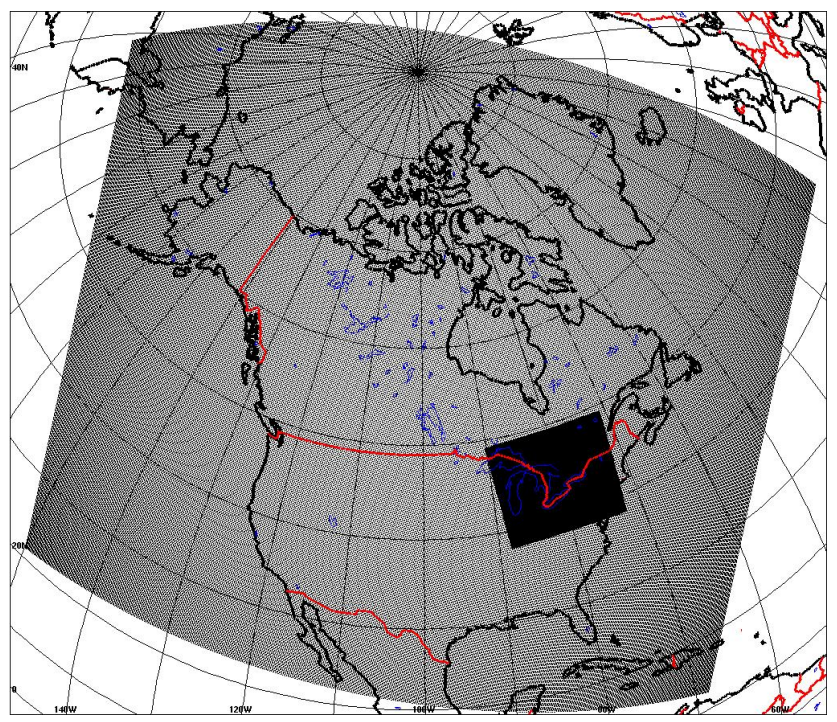

Fig. 1. GEM 15-km core domain and 2.5-km limited-area domain.

The GEM meteorology was created in a sequence of $12-\mathrm{h}$ runs, starting at 00:00, 06:00, 12:00, and 18:00 UT from objective analysis files for those times for the $15-\mathrm{km}$ simulation, the first six hours of these simulations being used for model spin-up, the last six hours being retained for AURAMS simulations. This methodology makes use of the meteorological data assimilation of the objective analysis to the maximum extent, to prevent drift of the predicted $15-\mathrm{km}$ meteorology from the observations.

Process representations in version 1.4.0 of the AURAMS CTM include emissions from surface and from elevated sources, horizontal and vertical advection, vertical diffusion, gas-phase, aqueous-phase, and inorganic heterogeneous chemistry, secondary organic particle formation, dry and wet deposition, and particle nucleation, condensation, coagulation, sedimentation, and activation. Particulate matter is represented by 12 size bins, each having nine chemical components (Gong et al., 2006)

A three-level internal nesting setup was used for the AURAMS CTM v1.4.0 simulations: the outermost grid, a 42$\mathrm{km} / 15$-min North American domain, drove a $15-\mathrm{km} / 15$-min Eastern North American domain, which in turn drove a 2.5$\mathrm{km} / 2$-min southern Ontario domain (Fig. 2). All three grids made use of a monthly-varying upper boundary condition for all advected chemical species, and the outermost domain also made use of time-invariant and vertically-varying chemical lateral boundary conditions, with the exception of $\mathrm{O}_{3}$, for which a dynamic tropopause-referenced boundary condition was applied (Makar et al., 2010), Twenty-eight terrainfollowing vertical levels stretched telescopically from the Earth's surface to $18.7 \mathrm{~km}$, with the first three levels at 0 , 13.9, and $55 \mathrm{~m}$ a.g.1. AURAMS' ozone predictions and related diagnostics will be the focus of the current work.

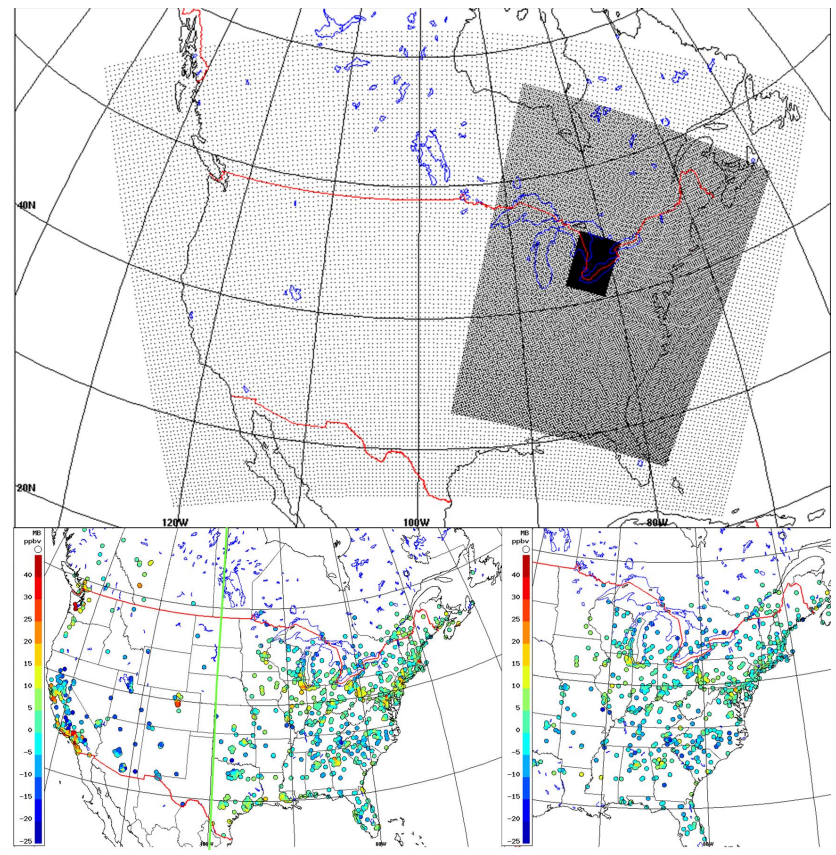

Fig. 2. (a) AURAMS 42-km, 15-km, and 2.5-km domains, (b) monitoring stations used for $42 \mathrm{~km}$ comparison to observations (Mean Bias shown; region east of $100^{\circ} \mathrm{W}$ is " $42-\mathrm{km}$-East"); (c) monitoring sites used for $15-\mathrm{km}$ comparison to observations (Mean Bias shown).

The base year for the anthropogenic emissions inventories processed by SMOKE version 2.2 was 2005 for the USA and for Canada and 1999 for Mexico. Biogenic emissions are calculated using BEIS3.09 algorithms, with model-generated temperatures and photosynthetically active radiation being used to create these emissions in-line during the AURAMS CTM runs.

\subsection{Simulation period and operating sequence}

Both GEM and the AURAMS CTM were run for the 3-month period from 1 June 2007 to 31 August 2007, for the GEM $15-\mathrm{km}$ domains. The GEM $15-\mathrm{km}$ meteorology was used to drive the AURAMS CTM at both 42 and $15 \mathrm{~km}$ for the same time period. The GEM 15-km meteorology was also used for boundary conditions for the higher resolution GEM $2.5-\mathrm{km}$ simulation, which in turn were used to drive the highest resolution AURAMS 2.5-km simulation. The GEM 2.5-km and AURAMS $2.5-\mathrm{km}$ simulations were only run for dates encompassing the BAQS-Met measurement intensive (17 June to 11 July 2007, the intensive itself being from 20 June to 10 July). The lateral boundary conditions for the $15-\mathrm{km}$ and $2.5-$ $\mathrm{km}$ AURAMS CTM simulations were taken from the corresponding coarser resolution simulations in each case; the climatological boundary condition was used for the model top in all three AURAMS simulations (Makar et al., 2010). 


\subsection{Model diagnostics: extraction of model values and mass tracking}

\subsubsection{Extraction of model values}

Times series of surface ozone at hourly intervals were extracted from the $42-\mathrm{km}$ and $15-\mathrm{km}$ AURAMS simulations for comparison to Aerometric Information Retrieval Now (AIRNow) real-time network observations (see www.airnow. gov). Both BAQS-Met mesonet ozone observations (5 min averages) and AURAMS $2.5-\mathrm{km} / 2$ min output were summed to create statistically comparable hourly values. Aircraft ozone observations (Hayden et al., 2010) were five second resolution data: these were binned to two minutes for comparison to AURAMS' output time step. The aircraft locations at $10 \mathrm{~s}$ intervals during each two minute model step were used to extract the model values along the observed 3-D flight path in the model coordinate system, and the average of these values during each 2 min interval was compared to the observations. The ozone measurements from the mobile laboratory CRUISER were one minute averages: the speed of the mobile laboratory is sufficiently slow that the nearest model gridpoint to the CRUISER location is sufficiently accurate for comparison purposes.

\subsubsection{Mass tracking of ozone}

AURAMS v1.4.0 includes an analysis package that records the change in mass of selected model species through each of the model's processes (the components of the net equation are solved as separate operators, Marchuk, 1975), expressed in units of ppbv/hour. These mass tracking options allow comparison of the gas-phase chemical production and loss, the advection, and the diffusion and deposition operators for ozone, within the AURAMS simulations. The relative magnitude and sign of the operators thus give information regarding the reasons for the model's ozone predictions, hence providing hypotheses for ozone formation, destruction, and transport, in the ambient atmosphere. This concept has appeared elsewhere in the literature under the name process analysis (cf. Jeffries and Tonnesen, 1994; Jang et al., 1995; Gipson, 1999).

\subsubsection{Sensitivity perturbation analysis of ozone and $\mathrm{HO}_{\mathrm{x}}$ precursors}

Ozone formation under polluted conditions is generally believed to be relatively insensitive to the details of the chemical mechanism employed in simulations (Chen et al., 2010; Kuhn et al., 1998). However, recent work (Chen et al., 2010) has also suggested that many regional model mechanisms predictions of the concentration of $\mathrm{HO}_{\mathrm{x}}\left(=\mathrm{OH}+\mathrm{HO}_{2}\right)$ may be biased low, possibly due to deficiencies in the model mechanisms. Here, $5 \%$ perturbations of the model's initial concentrations of volatile organic compounds and $\mathrm{NO}_{\mathrm{x}}$ (calculated at a specific hour on each simulated day and averaged over 23 days of simulatons) were used to spatially map the sensitivity of both ozone and $\mathrm{HO}_{\mathrm{x}}$ to precursor concentrations, hence determining the species with greatest impact on ozone and $\mathrm{HO}_{\mathrm{x}}$ levels in the region.

\section{Model performance evaluation}

The model performance for ozone prediction is evaluated here against the available observations, prior to its subsequent use as a tool for analysis of ozone formation in the lower Great Lakes. The performance evaluation thus quantifies the uncertainty associated with the subsequent analysis.

\subsection{AURAMS 42-km and 15-km ozone versus AIRNow observations}

Summary statistical comparisons between AIRNow and AURAMS hourly ozone concentrations on the $42-\mathrm{km}$ and 15 km grids for the period 3 June 2007 through 31 August 2007 are depicted in Table 1. Note that " $42-\mathrm{km}$ East" refers to a subsection of the 42-km domain compatible (but not congruent) with the $15-\mathrm{km}$ domain (region to right of green line, Fig. 2b), and "15-km BAQS-Met" refers to the subsection of the $15-\mathrm{km}$ domain corresponding to the $2.5-\mathrm{km}$ domain (see Fig. 1).

The ozone mean biases (MB, Table 1) decrease with increasing resolution, and become negative at the highest resolution (Table 2). The root mean square error (RMSE) also decreases with increasing resolution. The correlation coefficient $R$ increases slightly with increasing spatial resolution in Table 1 . The mean biases for the different metrics (daily $1-\mathrm{h}$ maximum, daily mean, and hourly values) are all very similar for the same grids. Overall, the $15-\mathrm{km}$ simulations show a higher statistical "skill" than the 42-km simulations (with the exception of the correlation coefficients for the portion of the 42-km grid which overlaps the 15-km grid ["42-km East"]).

\subsection{AURAMS 2.5-km ozone versus mesonet observations}

Statistical comparisons between the 2.5-km/2-min AURAMS simulations and the mesonet stations shown in Fig. 3 are given in Table 2. From Table 2, the further increase in model resolution considerably improves the model correlation coefficients relative to the lower resolution simulations of Table 1, though the mean biases are now negative. Simulated surface ozone therefore has the highest positioning/shape accuracy at the highest model resolution, while being biased low. This tendency for the surface ozone bias to become increasingly negative with increasing model resolution is associated with $\mathrm{NO}_{\mathrm{x}}$ titration of ozone, and will be examined in more detail in Sect. 4.3. 
Table 1. Evaluation statistics for 3 June 2007-31 August 2007, 42-km and 15-km AURAMS versus AIRNow. M_obs = observed mean, M_mod = model mean, $\mathrm{MB}=$ mean bias, $\mathrm{NMB}=$ normalized mean bias, $\mathrm{R}=$ correlation coefficient, $\mathrm{RMSE}=$ root mean square error.

\begin{tabular}{|c|c|c|c|c|c|c|c|c|c|c|c|c|}
\hline & \multicolumn{4}{|c|}{$\mathrm{O}_{3}$ daily $1-\mathrm{h} \max$} & \multicolumn{4}{|c|}{$\mathrm{O}_{3}$ daily mean } & \multicolumn{4}{|c|}{ Hourly $\mathrm{O}_{3}$} \\
\hline & $42-\mathrm{km}$ & $15-\mathrm{km}$ & $\begin{array}{c}42-\mathrm{km} \\
\text { east }\end{array}$ & $\begin{array}{c}\text { 15-km } \\
\text { "BAQS Met" }\end{array}$ & $42-\mathrm{km}$ & $15-\mathrm{km}$ & $\begin{array}{c}\text { 42-km } \\
\text { east }\end{array}$ & $\begin{array}{c}15-\mathrm{km} \\
\text { "BAQS-Met" }\end{array}$ & $42-\mathrm{km}$ & $15-\mathrm{km}$ & $\begin{array}{c}42-\mathrm{km} \\
\text { east }\end{array}$ & $\begin{array}{c}\text { 15-km } \\
\text { "BAQS-Met" }\end{array}$ \\
\hline M_obs (ppbv) & 56.8 & 57.7 & 55.6 & 57.9 & 32.6 & 33.3 & 31.7 & 33.6 & 33.0 & 33.7 & 32.1 & 34.0 \\
\hline M_mod (ppbv) & 60.7 & 58.3 & 59.2 & 58.2 & 39.7 & 36.4 & 38.9 & 35.9 & 39.9 & 36.6 & 39.0 & 36.0 \\
\hline MB (ppbv) & 3.8 & 0.6 & 3.6 & 0.3 & 7.2 & 3.1 & 7.2 & 2.3 & 6.9 & 2.8 & 7.0 & 2.0 \\
\hline RMSE (ppbv) & 14.9 & 13.4 & 13.7 & 13.8 & 11.8 & 9.4 & 10.9 & 9.5 & 17.2 & 15.8 & 16.2 & 15.6 \\
\hline
\end{tabular}

Note: "42-km east" denotes statistics computed for sites east of $100^{\circ} \mathrm{W}$ within the continental 42-km domain; "BAQS-Met" denotes statistics computed for sites within an area bound by $40.5-44.5^{\circ} \mathrm{N}$ and $84-78^{\circ} \mathrm{W}$. Number of stations: $42-\mathrm{km}$ : $1167,42-\mathrm{km}$ east: $833,15-\mathrm{km}$ : $681,15-\mathrm{km}$ "BAQS-Met": region bounded by 40.5 to $44.5^{\circ} \mathrm{N}$ and 78 to $84^{\circ} \mathrm{W}$.

Table 2. Ozone statistics at all BAQS-Met surface mesonet stations, 2.5-km resolution simulations.

\begin{tabular}{lrrrr}
\hline Statistic & $\begin{array}{r}\mathrm{O}_{3} \text { hourly } \\
\text { averages }\end{array}$ & $\begin{array}{r}\mathrm{O}_{3} \text { daily } \\
\text { mean }\end{array}$ & $\begin{array}{r}\mathrm{O}_{3} \text { daily } \\
1 \text {-h max }\end{array}$ & $\begin{array}{r}\mathrm{O}_{3} \text { daily } \\
1 \text {-h min }\end{array}$ \\
\hline M_obs (ppbv) & 41.2 & 41.8 & 63.2 & 21.5 \\
M_mod (ppbv) & 33.3 & 33.9 & 54.5 & 16.6 \\
MB & -7.89 & -7.90 & -8.82 & -4.84 \\
NMB & -0.19 & -0.19 & -0.14 & -0.23 \\
$R$ & 0.80 & 0.82 & 0.77 & 0.72 \\
RMSE (ppbv) & 14.2 & 10.9 & 14.9 & 11.0 \\
\hline
\end{tabular}

\subsection{AURAMS 2.5-km ozone versus aircraft observations}

Statistical comparisons between the $2.5-\mathrm{km} / 2-\mathrm{min}$ AURAMS simulations and the entire sequence of flights, and for individual flights, to the aircraft observations, are shown in Table 3. The "All Flights" statistics show a correlation coefficient of 0.74 , slope of 0.87 , intercept of $-2.7 \mathrm{ppbv}$, a mean bias of $-10.3 \mathrm{ppbv}$, and a mean error of $12.8 \mathrm{ppbv}$. The model biases aloft are often negative, similar to Table 2 . The high resolution model thus has the tendency to be biased lower for ozone aloft than at the surface. Figure 4 shows the observed time series, simulated time series, correlation scores and mean biases for all flights. Most flights have negative mean biases; the model (thick line on the figures) is biased low relative to the observations (white diamonds).

Both the observations and the model show the presence of relatively short duration changes in the ozone concentration, indicating local-scale perturbations in the ozone field. For example, flight 2 (Fig. 4b) shows peak-to-trough ozone concentration variations of $15 \mathrm{ppbv}$ over durations of $4 \mathrm{~min}$, flight 14 (Fig. $4 \mathrm{n}$ ) shows peak-to-trough variations of

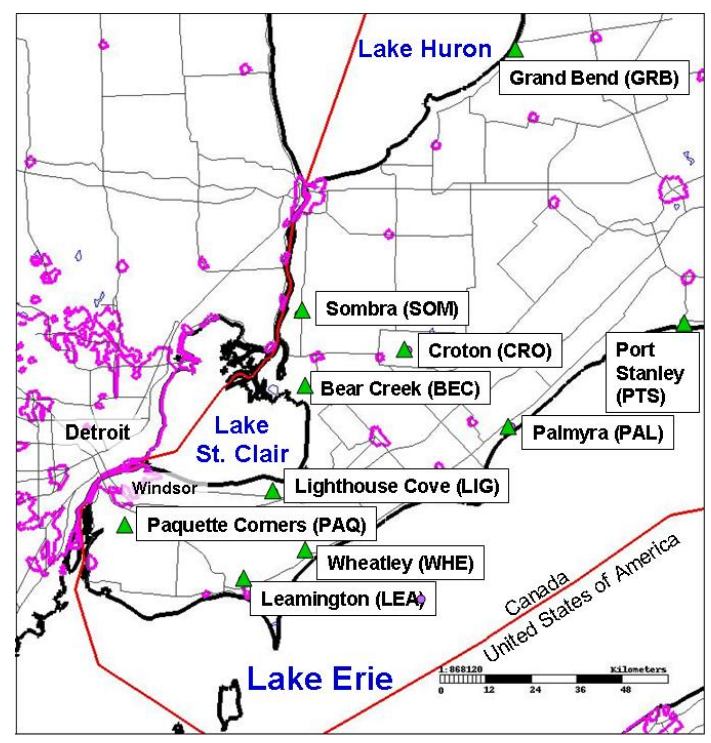

Fig. 3. Locations of BAQS-Met surface mesonet stations (green triangles). Urban region outlines in mauve, international border in red.

30 ppbv over 26 min duration in both the observations and the simulations. The typical flying speed of the Twin Otter is $60 \mathrm{~m} \mathrm{~s}^{-1}$, indicating that these ozone features have trough-totrough spatial scales of 28 to $94 \mathrm{~km}$. Superimposed on these are even shorter time interval events; for example, Flight 9 (Fig. 4i) shows two peaks each of duration $8 \mathrm{~min}(29 \mathrm{~km})$ with peak-to-trough variation of $20 \mathrm{ppbv}$. Both the observations and the model thus suggest the presence of small spatial-scale ozone features. Our subsequent analysis below (Sect. 4) examines the manner in which these features are formed. 


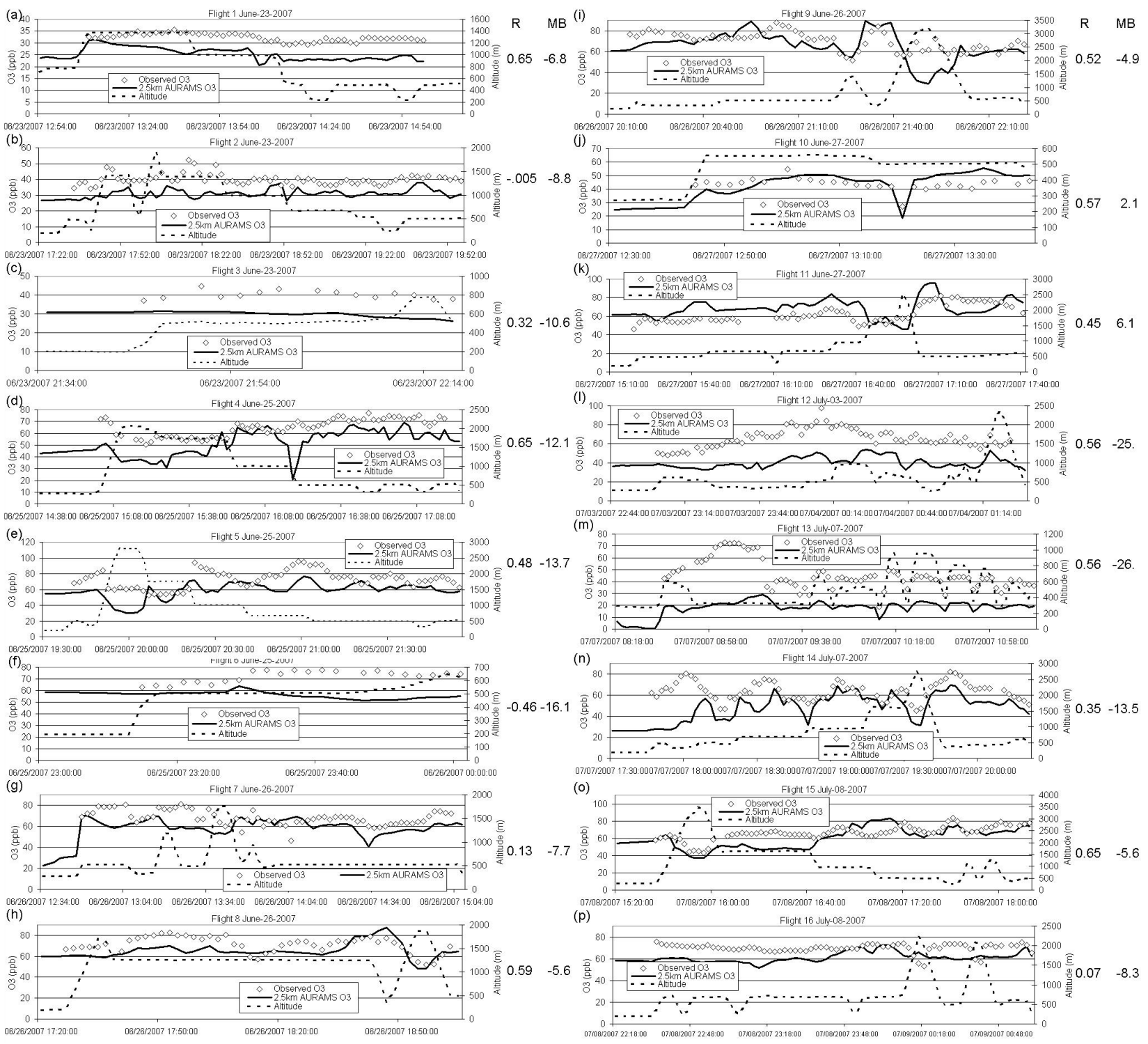

Fig. 4. (a-h) Observed and simulated $\mathrm{O}_{3}$ (ppbv), first 8 flights. (i-p) Observed and simulated $\mathrm{O}_{3}$ (ppbv), remaining 8 flights.

\subsection{AURAMS 2.5-km ozone versus ozonesonde observations}

Ozonesonde observations were carried out at the Harrow supersite at $12 \mathrm{~h}$ intervals during the study. Model profiles were extracted from each horizontal resolution of the model simulations at the same times as the ozonesonde releases. The 2.5$\mathrm{km}$ model results and the observations are compared in Fig. 5 for the intensive period. Both model and observations show a tropopause fold occurring at the start of the time period (20 June); ozone concentrations greater than 120 ppbv reach elevations as low as $7 \mathrm{~km}$ a.g.l. in the observations. The model shows two later similar events, some indication of which may be present in the observations, but are difficult to distinguish due to missing data. In the model results, these high concen- trations extend down to the 5-km level. Stratospheric intrusions observed by ozonesondes and other measurements during the study period were captured by the model; however, they appear to have had only a modest influence on surface ozone, which is much more heavily influenced by chemistry and transport close to the ground.

A detailed study of stratospheric/tropospheric exchange during the measurement intensive is presented in $\mathrm{He}$ et al. (2010). The AURAMS ozone predictions at mid and upper tropospheric levels, and the dependence of these predictions on the manner in which upper and lateral boundary conditions are prescribed have been the focus of a separate research project, reported elsewhere in this issue (Makar et al., 2010). 
Table 3. Summary ozone statistics for aircraft flights.

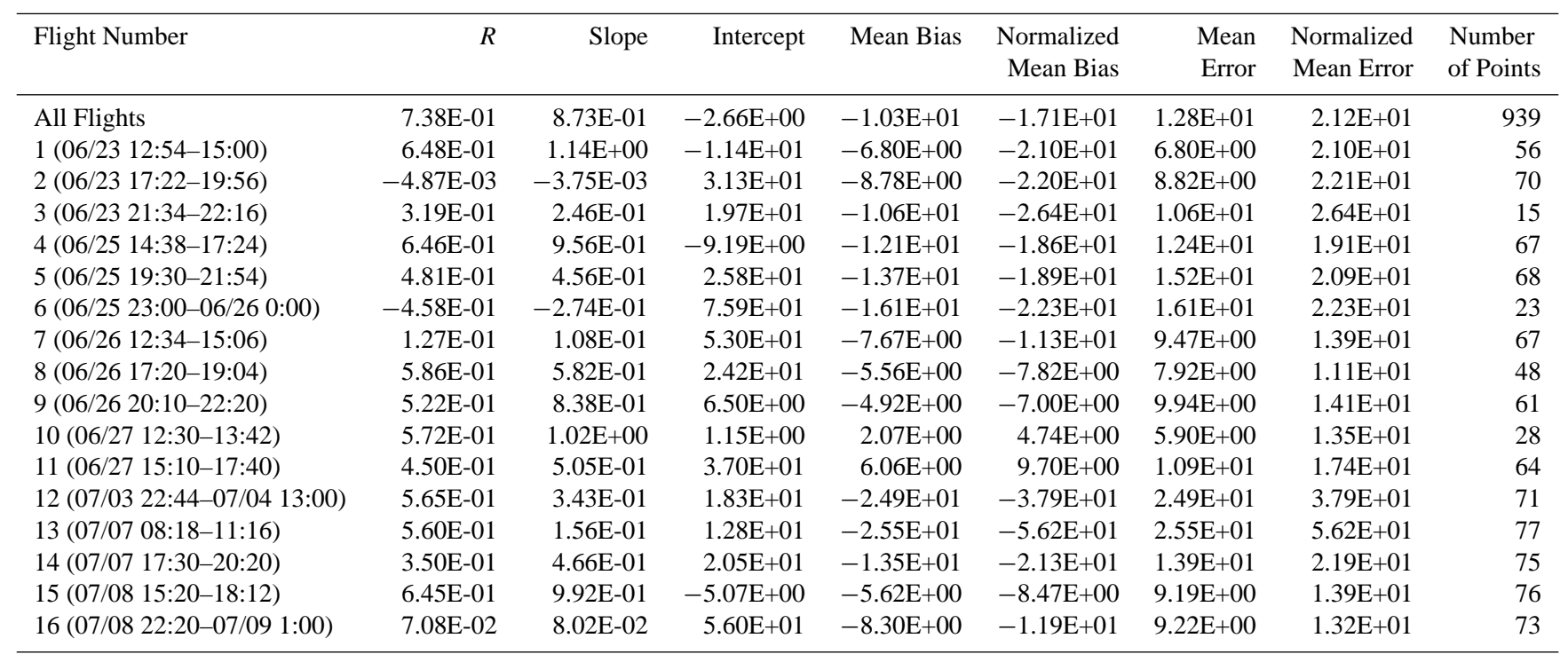
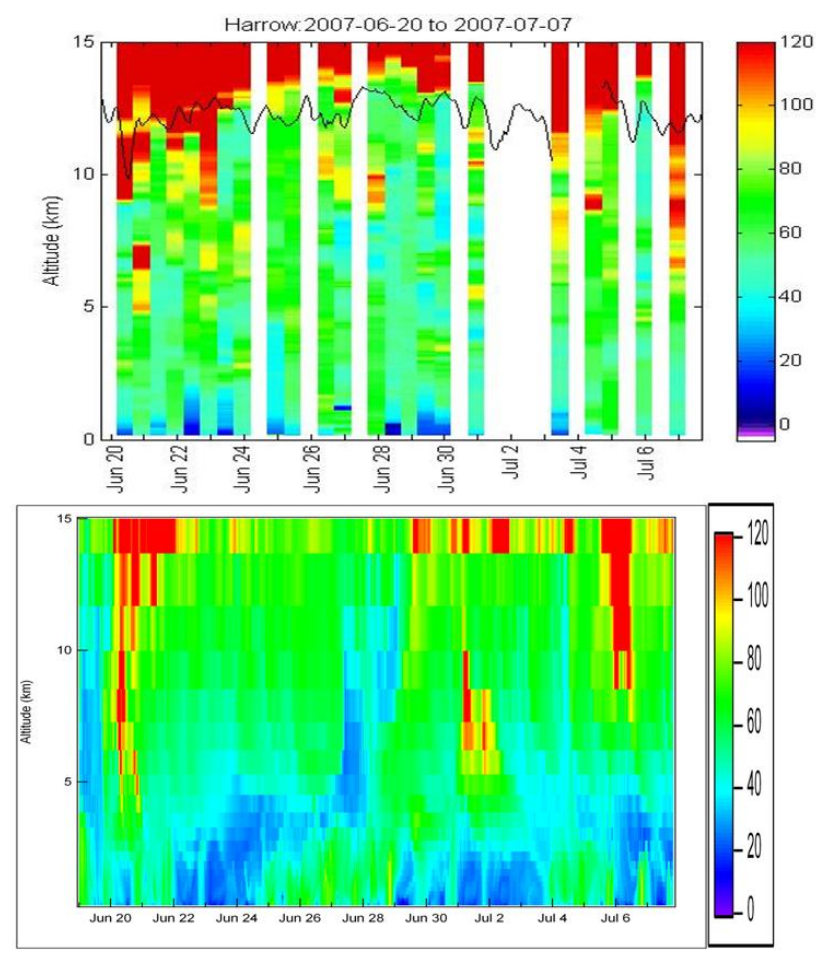

Fig. 5. (a) Observed ozone profiles from sondes, (b) modelsimulated ozone profiles.

\subsection{AURAMS 2.5-km ozone versus CRUISER observations}

Ozone and other observations were made on the CRUISER mobile laboratory, which spent the majority of its time parked at its "home base" in west Windsor, including every night during the study. However, on 12 separate days CRUISER spent daytime and evening hours collecting mobile measurements along roadways in the region, or at strategic locations. CRUISER driving routes during the intensive are shown in Fig. 6a, b and c compare model and observed $\mathrm{O}_{3}$ and $\mathrm{NO}_{2}$, respectively, for the entire period. AURAMS ozone along the CRUISER driving routes is generally biased low (comparing all two minute model values with corresponding averaged observations: $\mathrm{MB}-24 \mathrm{ppbv}, \mathrm{NMB}$ -0.55 , RMSE 32 ppbv, correlation coefficient $(R) 0.63)$. Nitrogen dioxide was biased high (Fig. 6c), suggesting that the negative biases in the ozone values are the result of excessive $\mathrm{NO}_{\mathrm{x}}$ titration of ozone in the model. These biases are much more negative than that seen at the surface mesonet stations (e.g. compare to Table 2, $\mathrm{O}_{3}$ hourly average mean bias of $-7.89 \mathrm{ppbv})$. The implication is that the model in its current form is unable to capture the very local mixing of freshly emitted $\mathrm{NO}_{\mathrm{x}}$ associated with the roadways' mobile sources with the regional, $\mathrm{O}_{3}$ enriched airmass. This results in large positive biases in $\mathrm{NO}_{\mathrm{x}}$ close to the roadways, but once the $\mathrm{NO}_{\mathrm{x}}$ has been dispersed to the more rural locations of the mesonet, the fit to the observations improves. 


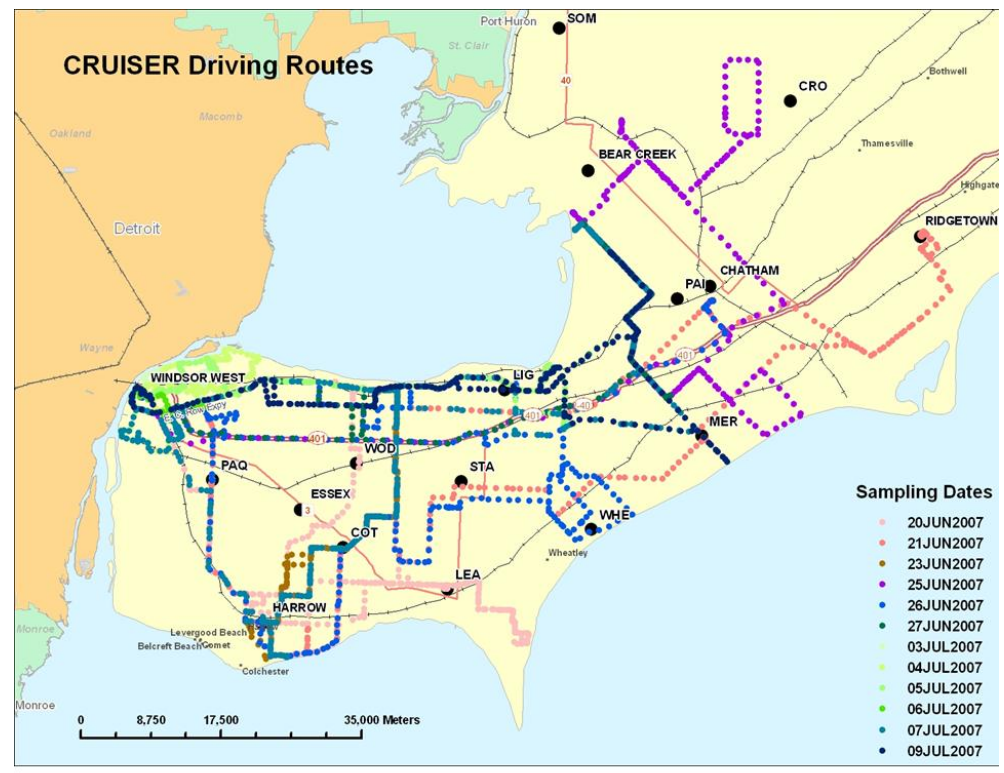

CRUISER and $2.5 \mathrm{~km}$ AURAMS 03
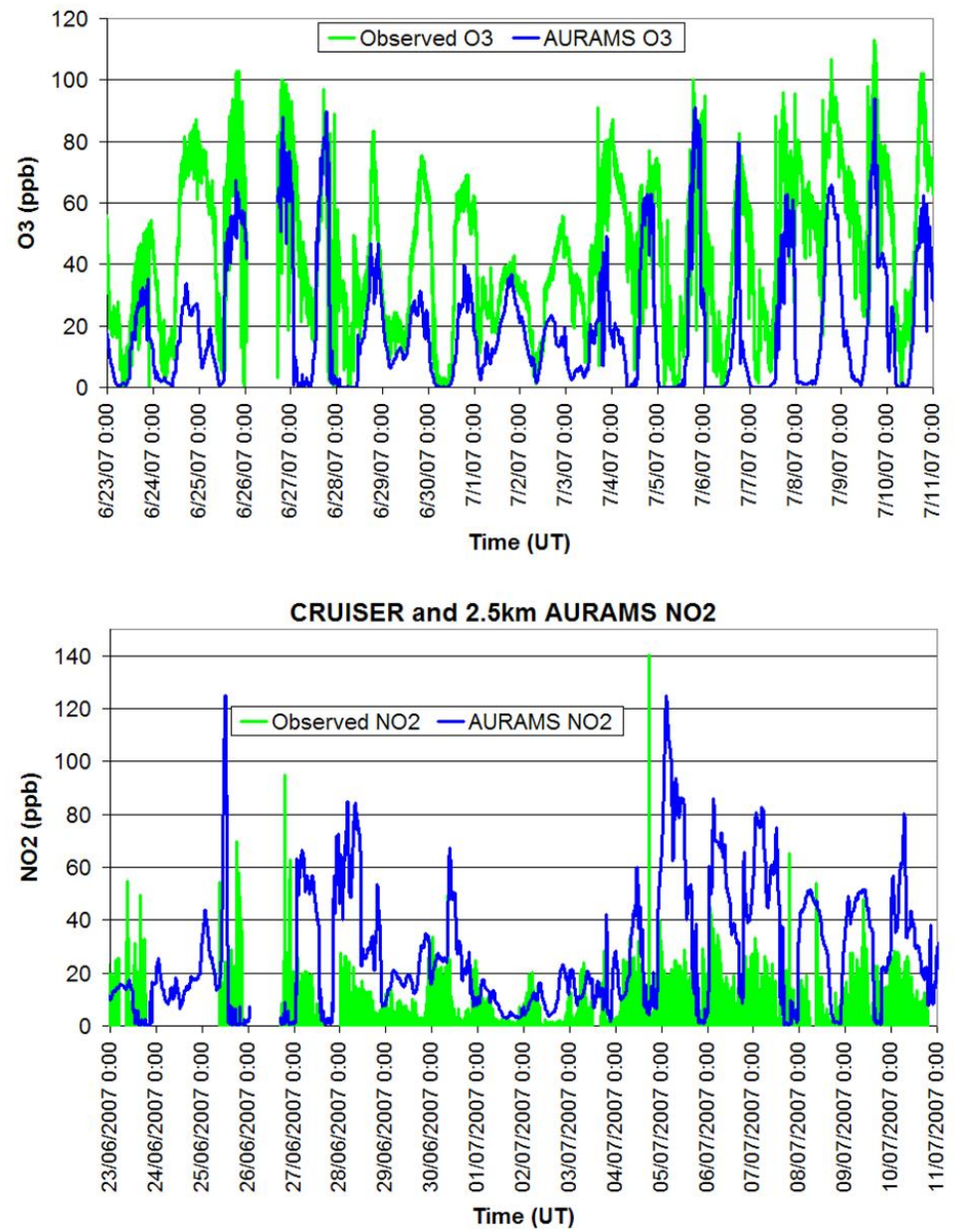

Fig. 6. (a) CRUISER driving routes during the intensive, (b) observed and model-simulated ozone along CRUISER driving routes, (c) observed and simulated $\mathrm{NO}_{2}$ along CRUISER driving routes. 


\subsection{Summary, comparisons to ozone observations}

The above statistical comparisons suggest:

1. the highest resolution model simulations give the best comparison to observations for surface ozone;

2. for those simulations, the model has a negative bias at the surface of -4 to $-9 \mathrm{ppbv}$, depending on the metric chosen;

3. the model compares well to ozonesonde observations over the depth of the troposphere; these suggest that lower tropospheric ozone is not significantly affected by stratospheric intrusions, despite their occurrence during the study period;

4. the model is biased very low along the roadway networks $(-23$ ppbv), but this does not affect the regional ozone predictions, suggesting that the low bias is the result of inadequate resolution of the very local scale emissions and turbulence over the roadways;

5. the surface level negative bias increases to $-10.3 \mathrm{ppbv}$ at aircraft altitudes.

6. the aircraft observations and model also suggest the presence of very local-scale features in the ozone concentrations.

\section{Model-predicted causes of ozone formation and destruction over the Great Lakes: $2.5-\mathrm{km}$ resolution analyses}

\subsection{Case studies}

We turn now to the use of the model as an analysis tool to explain surface and lower troposphere ozone formation in the study region. During the three-week duration of the measurement intensive, specific patterns of circulation and ozone concentrations tended to recur, depending on the synoptic winds. Specific patterns occurred with sufficient frequency to be useful as archetypes for the given circumstances for ozone formation. We examine these archetypes below with case studies (additional case studies are examined in Levy et al., 2010), and then use 23-day averages of model output to explain the underlying causes of enhanced ozone formation in this region.

\subsubsection{June, 10 July 2007: Lake St. Clair lake-breeze front enhancement of ozone north of Detroit}

The following example demonstrates the very local nature of ozone enhancements associated with lake-breeze front convergence, how this circulation concentrates precursors, and how it results in downwind ozone increases, even after photochemical production has ceased. Mesoanalysis wind fields and lake-breeze front lines (the latter inferred from the measured winds as well as satellite cloud analysis and radar fineline analysis, see Sills et al., 2010) are shown in Fig. 7a . Weak synoptic winds are from the south-west, and are perturbed locally by strong lake breezes. South of Lake Erie, the lake-breeze front extends up to $50 \mathrm{~km}$ inland by 23:00 UTC (07:00 p.m. local daylight time). The lake-breeze front west of Lake Erie and the front from Lake St. Clair create a region of weak surface convergence to the west of Lake St. Clair. The Lake Huron front is pushed northwards over that lake by the synoptic flow. Figure $7 \mathrm{~b}$ shows the corresponding wind fields and fronts (the latter inferred from convergence regions in the wind fields) predicted by GEM. There is a good correspondence in the locations of the main convergence lines in the vicinity of the lakes between model and observations (compare Fig. 7a and b), though GEM tended to overpredict convection during this period (gust fronts in Fig. 7b, south of Lake Erie).

Figure 8 shows the corresponding model-predicted surface ozone concentration and wind at 18:00 and 23:00 UT (02:00 p.m. and 07:00 p.m. local time), and along a vertical cross-section, illustrating the ozone structure through the frontal convergence lines. Wind fields are shown as the components of the 3-D wind in the plane of the cross-section, in knots, with the vertical component scaled according to the vertical versus horizontal axis scaling. High concentration (>80 ppbv) ozone starts to appear by 02:00 p.m. local time (Fig. 8a, b), and continues to increase through 07:00 p.m. local time (Fig. 8c, d). The location of the ozone maxima is strongly linked to the locations of the lake-breeze front convergence lines; locations "a" and "b" along the cross-section at 18:00 UT (Fig. 8b) show that the locations of the high concentrations of ozone extend to $2 \mathrm{~km}$ altitude, and correspond to updraft/downdraft pairs generated by surface-level convergence.

Mass tracking depicted in Fig. 9 shows that the ozone is created photochemically in the early afternoon in narrow bands along the convergence zones and aloft (e.g. locations "a", "b", Fig. 9a), and that this photochemically produced ozone is transported both upwards and downwind (Fig. 9b; blue regions indicate $\mathrm{O}_{3}$ removal by transport, note matching in position to red photochemical production regions in Fig. 9a). By late afternoon, the photochemical production source has shut down leaving only $\mathrm{NO}_{\mathrm{x}}$ titration removing ozone (blue regions, Fig. 9c), though ozone increases are still occurring due to transport associated with ozone created upwind earlier in the day (red regions, Fig. 9d). These findings are similar to the behind-front net convergence of ozone and precursors noted by Drobinski et al., 2007, with the added information that the regions of convergence and enhanced ozone concentrations have a substantial vertical extent.

Observed surface ozone on 26 June is compared to model predictions in Fig. 10, for sites arranged from south to north near the border (Sombra station, Fig. 3, was not operating that day). Model and observations are within $10 \mathrm{ppbv}$ and 

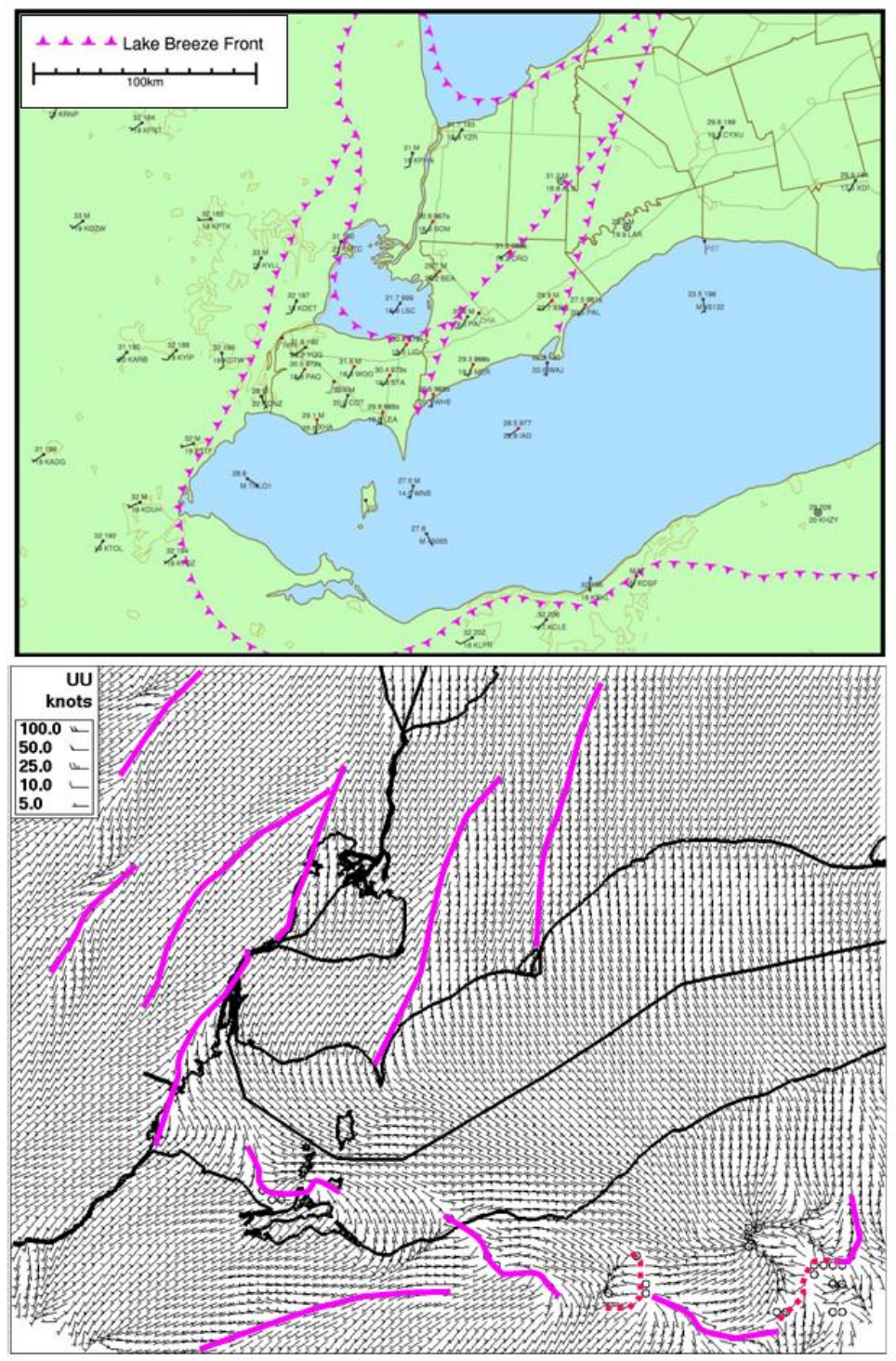

Fig. 7. 26 June, 23:00 UT (07:00 p.m. local time) (a) meso-analysis lake-breeze front locations; (b) lake-breeze front locations inferred from convergence pattern of $2.5-\mathrm{km}$ resolution model winds.

usually within $5 \mathrm{ppbv}$ at Paquette Corners (Fig. 10a), while Bear Creek (Fig. 10b) is biased low by $20 \mathrm{ppbv}$ at midday, and the model is biased -70 ppbv during the observed ozone maximum at Grand Bend (Fig. 10c). This large negative bias is apparently due to a small error in the wind direction. Figure $10 \mathrm{~d}$, e shows the model-predicted surface ozone concentrations in the area at 18:00 UT and 23:00 UT, respectively, along with the three site locations. High ozone concentrations downwind of the Sarnia and Lambton plumes are predicted by the model in the vicinity of Grand Bend (Fig. 10d), but these remain off-shore for most of the day, and come onshore to the north-east of the station, in contrast to the observations. The model results suggest that the high values are associated with these plumes, and that the duration of the
Lake Huron lake breeze circulation at 18:00 UT was greater in the ambient atmosphere than in the simulation. Very similar patterns of ozone formation under south-westerly synoptic winds were observed on other days, with the highest concentrations in the observations and model records occurring at Grand Bend station.

This analysis has several common features with the other examples of model-predicted lake-breeze front ozone formation which follow in subsequent sections: (a) ozone photochemical production just outside precursor source regions in the early afternoon (in subsequent analysis we show that on average these photochemical production areas maximize over the lakes); (b) lake-breeze fronts result in local convergence of both ozone and precursors at the surface and 


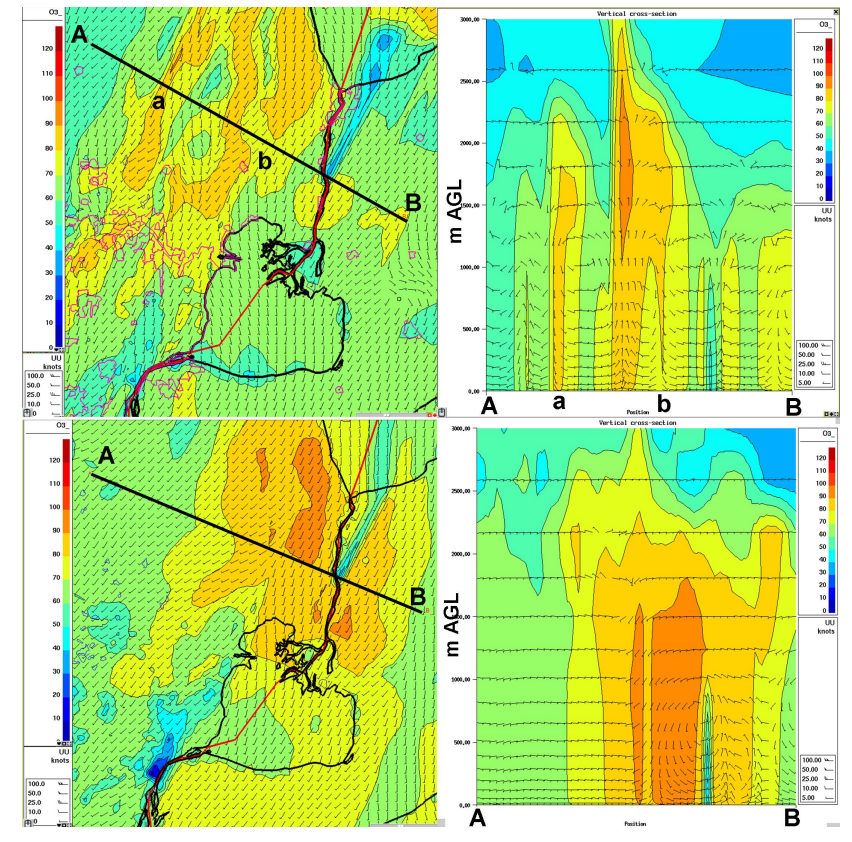

Fig. 8. Model-predicted fields for 26 June. 18:00 UT (02:00 p.m. local time): (a) Surface ozone and wind barbs; (b) vertical profile of ozone and winds along cross-section A-B. (c, d): as in $(a, b)$, but at 23:00 UT (07:00 p.m. local time).

subsequent lofting of these species in the frontal convergence zone, similar to Drobinski et al. (2007); (c) early evening increases in ozone concentration continue in the convergence zones, despite photochemical production having shut down earlier.

\subsubsection{July 2007, 9 July 2007, 27 June 2007: long-range transport of ozone along lake-breeze frontal convergence zones}

The previous example showed that frontal convergence lines may be responsible for local ozone enhancements with length scales on the order of $100 \mathrm{~km}$. Here, we show that these features may extend for much larger distances. 27 June, 8 July and 9 July were days with moderate south-westerly synoptic winds coupled with strong lake breezes reaching far inland and downwind of the lakes themselves (Sills et al., 2010). 8 July is examined here as an example (note that Flight 15 on 8 July, Table 3 , has the 2 nd highest $R$ value of the flight simulations). Figure 11a shows the mesoanalysis front locations at 17:00 UT (01:00 p.m. local time), which compare well with the model-predicted wind fields and surface convergence regions (Fig. 11b). The northern-most convergence line (circled in blue, Fig. 11b) will be examined in more detail (Figs. 12 and 13) Figure 12a shows a time-series comparison between model predictions and observations of surface ozone at Sombra station. The model is biased low by approximately $20 \mathrm{ppbv}$ at night. The model fit is better dur-

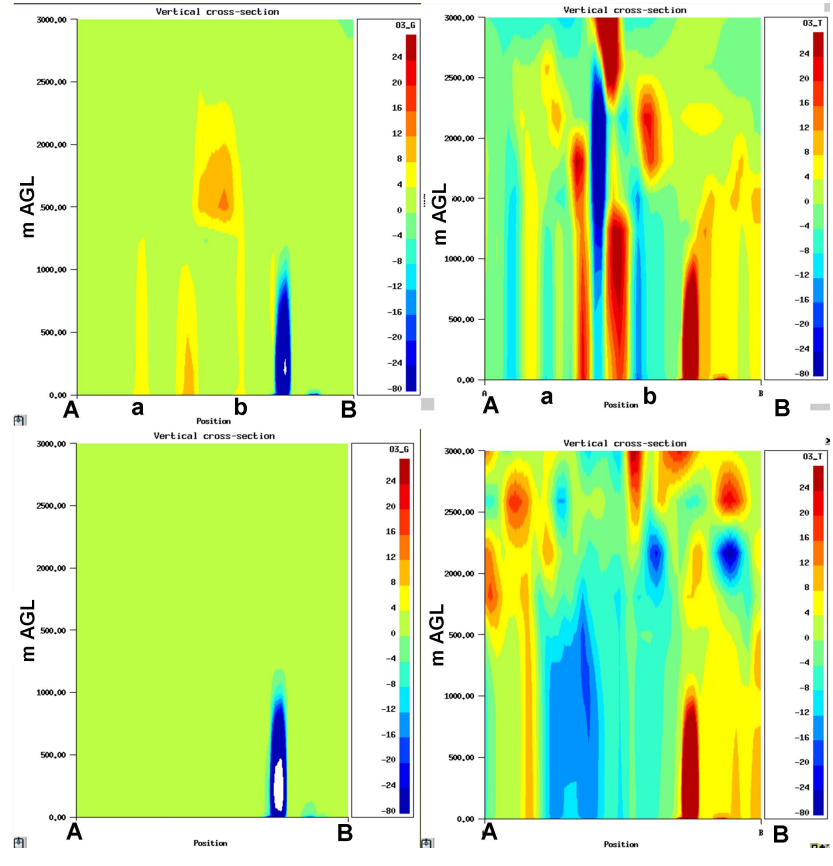

Fig. 9. 18:00 UT (02:00 p.m. local time): (a) gas-phase photochemical production and loss along cross-section A-B of Fig. 8; (b) total transport rate of change of ozone along cross-section A-B of Fig. 8. (c, d): as in (a, b), but at 23:00 UT (07:00 p.m. local time).

ing the day, when both model and measurements show short time duration ozone peaks during midday, the model leading observations by an hour. Figure $12 \mathrm{~b}$ shows that the modelpredicted surface ozone field at Sombra is part of an elongated feature of high ozone along the more northern of the two convergence lines, a feature extending over $300 \mathrm{~km}$ from Detroit to Toronto.

The panels of Fig. 13 show that ozone is photochemically created (red regions, Fig. 13a) between the surface and heights of $1600 \mathrm{~m}$ above the surface, near the cities and downwind of the region north-east of Lake St. Clair. The ozone production regions are sometimes detached from the surface, with maxima between 1000 and $1400 \mathrm{~m}$. Transport (both horizontal and vertical) is removing ozone away from these photochemical production regions (note correspondence of blue areas, Fig. 13b, to red areas, Fig. 13a). Transport increases the ozone concentrations at elevations above $1600 \mathrm{~m}$, downwind and along the surface convergence line (red areas, Fig. 13b). Three dimensional surface plotting of the transport terms (not shown) suggests that they are driven by the local flow rather than the synoptic winds; the highest transport levels are along the convergence line.

An ozone cross-section between Lake Huron and Lake Erie across this feature at the same time (Fig. 14) suggests that high concentration ozone is associated with helical circulation in the vicinity of the lake-breeze convergence lines (Fig. 12b shows that the wind field is largely aligned along 

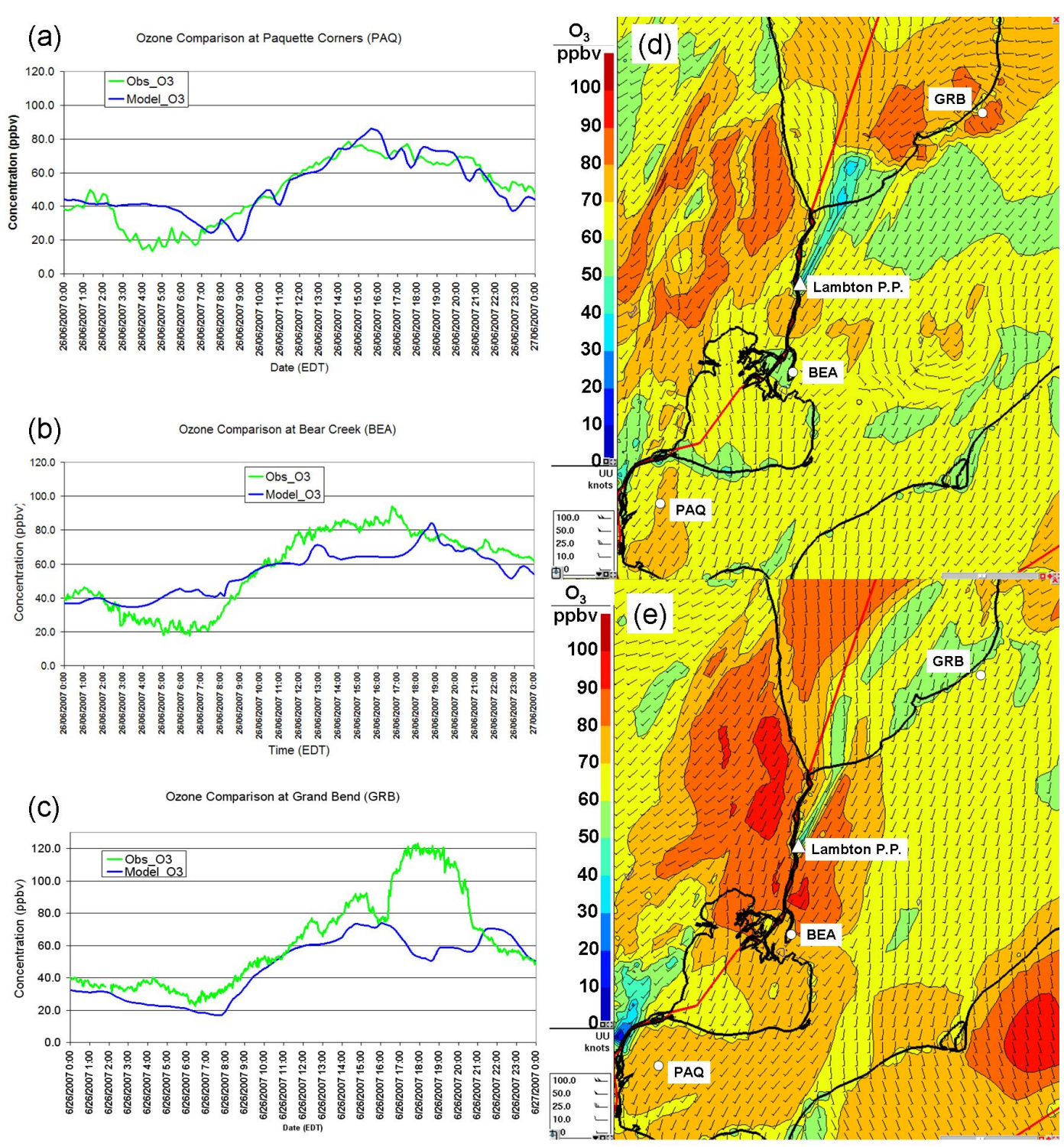

(c)

Ozone Comparison at Grand Bend (GRB)

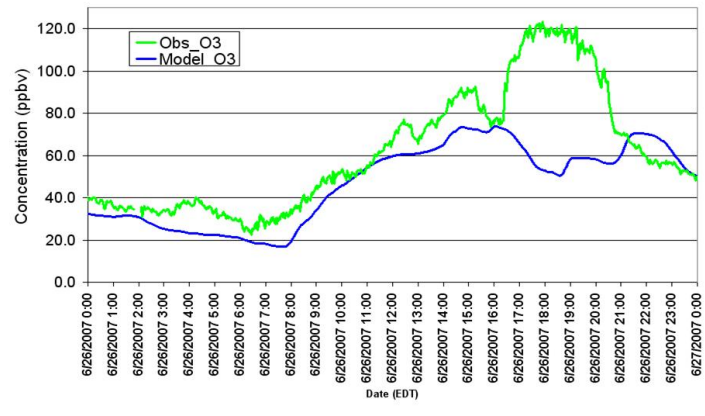

Fig. 10. Ozone comparison with surface observations, 26 June, at (a) Paquette Corners, (b) Bear Creek, (c) Grand Bend. Model surface ozone concentrations at (d) 18:00 UT (02:00 p.m. local time) and (e) 23:00 UT (07:00 p.m. local time).

the length of the convergence zone, while Fig. 14, looking in the direction of that flow, shows a clockwise circulation at $1000 \mathrm{~m}$ aloft at the cross-section centre, and plumes of ozone becoming detached from the surface in response to these circulation patterns. This helical transport pattern has been noted in other high resolution model simulations (Lyons et al., 1995).

As in Sect. 4.1.1, the above analysis suggests that the surface convergence zones associated with lake breezes can increase photochemical ozone production just downwind of precursor source regions by confining and hence increasing precursor concentrations, similar to the findings of Drobinski et al. (2007). Ozone concentrations are also enhanced still further downwind, via transport of ozone and its precursors along the convergence line. Extended features of high concentration ozone may become detached from the surface, and travel considerable distances (hundreds of $\mathrm{km}$ ) downwind of the source regions. These ozone plumes may eventually fumigate downwards, depending on conditions further downwind (for example, the ozone aloft might be brought to the surface on a subsequent day during boundary layer growth, or the ozone aloft may be caught up in a downwind urban heat island circulation).

These regions of enhanced ozone are relatively small (10's of $\mathrm{km}$ across, though up to $330 \mathrm{~km}$ long, in the above example), and may be difficult to accurately position with a model, relative to the ambient atmosphere. However, observations from the mesoscale monitoring network often capture 


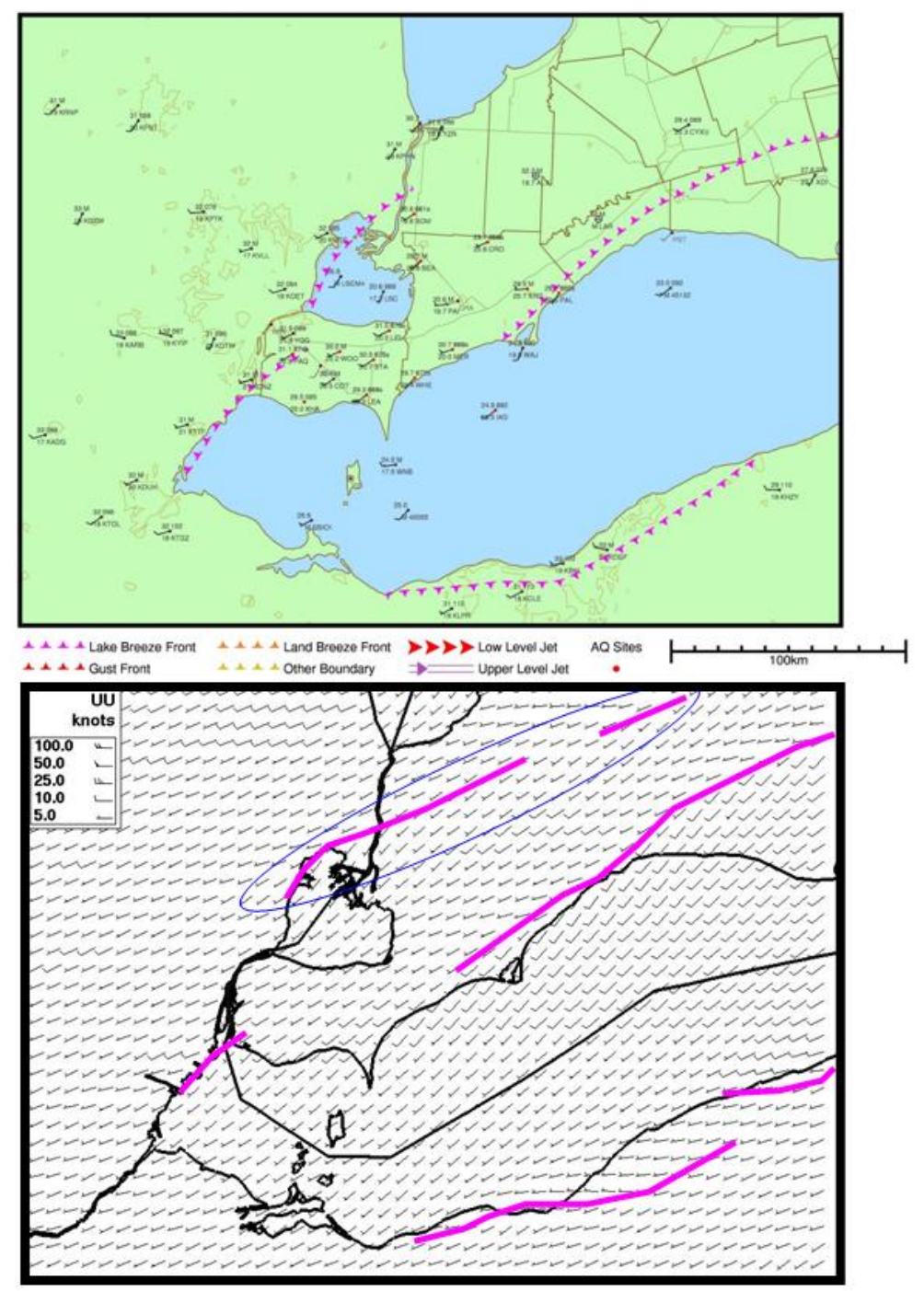

Fig. 11. (a) Meso-analysis lake-breeze front locations on 8 July, 17:00 UT (01:00 p.m. local time); (b) model-predicted surface wind field and convergence zones.

very similar features in the ozone time series, with the model demonstrating good agreement. An example of this can be seen in the measurement record for 27 June. Figure 15 shows the observed (green) and simulated (blue) time series at Bear Creek (Fig. 15a), Croton (Fig. 15b) and Port Stanley (Fig. 15c). Both model and observations show a midday "spike" in ozone concentrations (observed: $80 \mathrm{ppbv}$ maximum, model: $90 \mathrm{ppbv}$ ). Hourly ozone concentration contours from 16:00 to 19:00 UT (Fig. 16) show that the Bear Creek and Croton maxima are associated with a convergence line similar to that of Fig. 12, while the Port Stanley high is associated with the lake breeze front along the north shore of Lake Erie. These observation time series show that very local events associated with lake circulation are capable of enhancing the ozone concentrations by over $30 \mathrm{ppbv}$ relative to the surrounding regions. The model simulations suggest that these events are closely linked to the local circulation in the vicinity of the Lakes.

\subsection{Averages of model fields: the average impact of transient events}

The events described above are transient in that they may last over the course of a few hours on any given day. In order to determine the impact of these transient events over a longer time frame, hourly model output for the ozone concentration, mass tracking fields and winds for the 23 days (19 June to 11 July) were averaged for each hour of the day. As will be demonstrated in the following analysis, these averages show: 

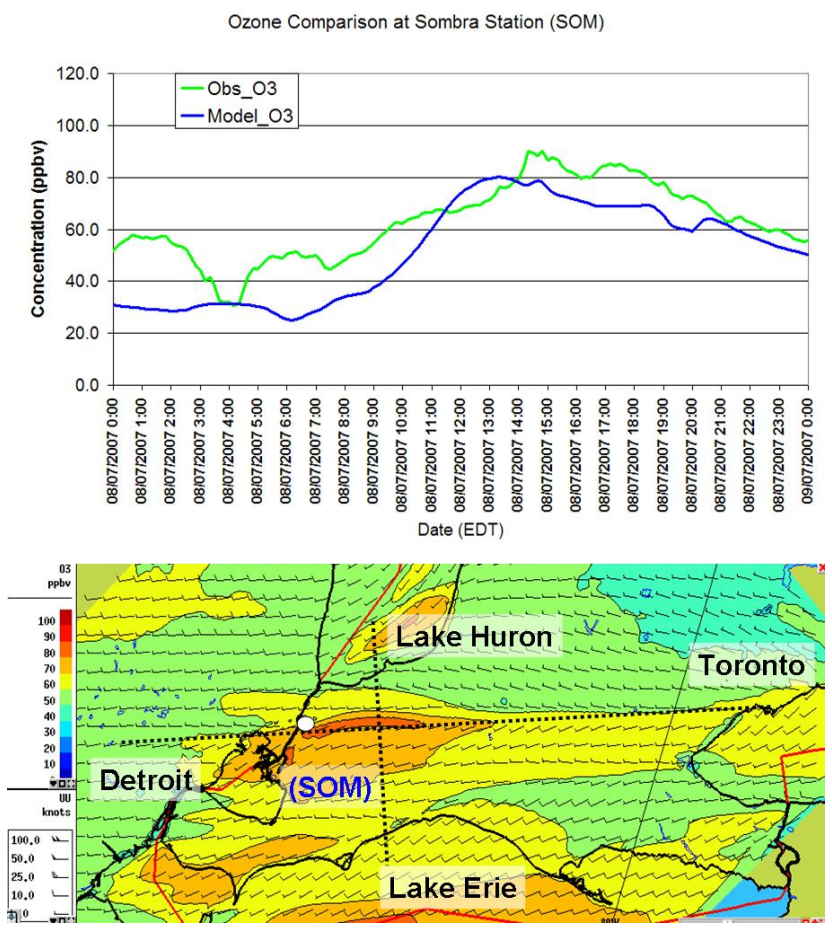

Fig. 12. (a) Model-predicted ozone versus observations, 8 July, Sombra station. (b) Model-predicted surface ozone and surface winds at 17:00 UT (01:00 p.m. local time).

1. the lake-breeze circulation has a consistent average diurnal pattern;

2. this circulation has a significant impact on the average ozone in the region;

3. Lakes St. Clair and Erie are regions of intense photochemical ozone production, though the vertical extent of these regions varies greatly between the two lakes;

4. helical (re-) circulation of pollutants over the lakes may intensify ozone production there.

\subsubsection{Hour-average surface horizontal winds}

Figure 17 shows the 23-day averages of the surface wind field at 12:00, 16:00, 20:00 and 00:00 UT (08:00 a.m., 12:00 p.m., 04:00 p.m., and 08:00 p.m. local time). By noon (Fig. 17b), lake-breeze convergence zones (solid mauve lines) appear on the south west shore of Lake Huron, the west shore of Lake St. Clair, the west and north shores of Lake Erie, and the north shore of Lake Ontario. Each of these lakes in Fig. 17b also contains a region of surface divergence; the outflow from this divergence region perturbs the synoptic flow (limits of this outflow region are indicated by dashed mauve lines). The convergence zones persist through 04:00 p.m. (Fig. 17c), and the outflow regions push considerable distances inland. By 08:00 p.m. (Fig. 17d) the impact of the lake breezes becomes

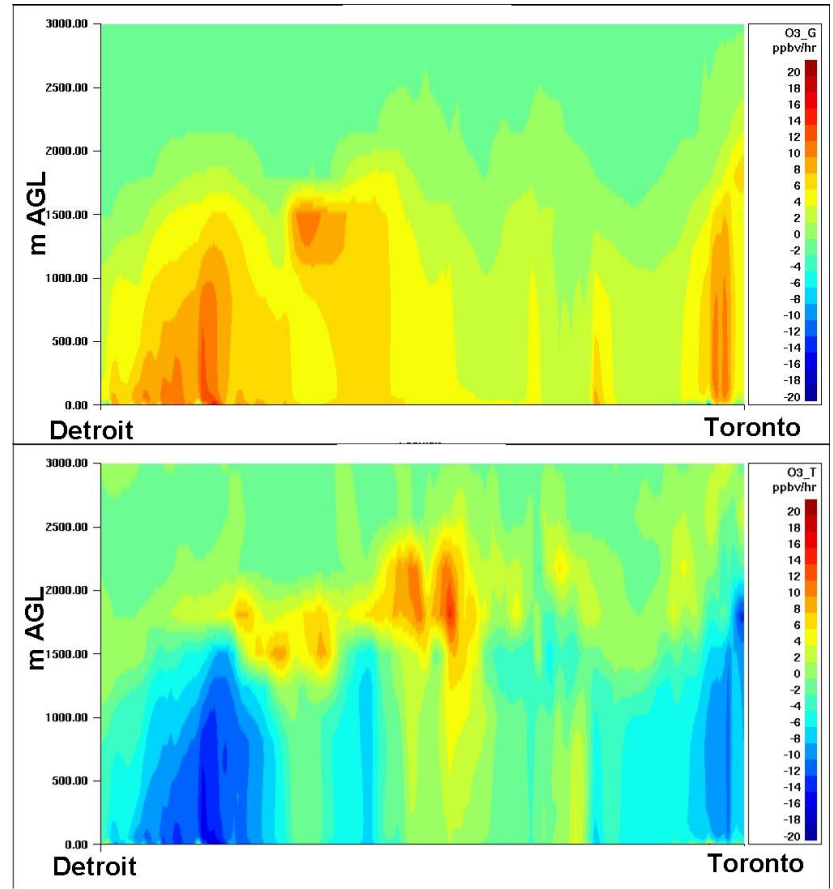

Fig. 13. Model-predicted ozone mass tracking fields for 8 July, 17:00 UT (01:00 p.m. local time), Detroit to Toronto cross-section. (a) Gas-phase photochemical production, and loss; (b) total transport rate of change.

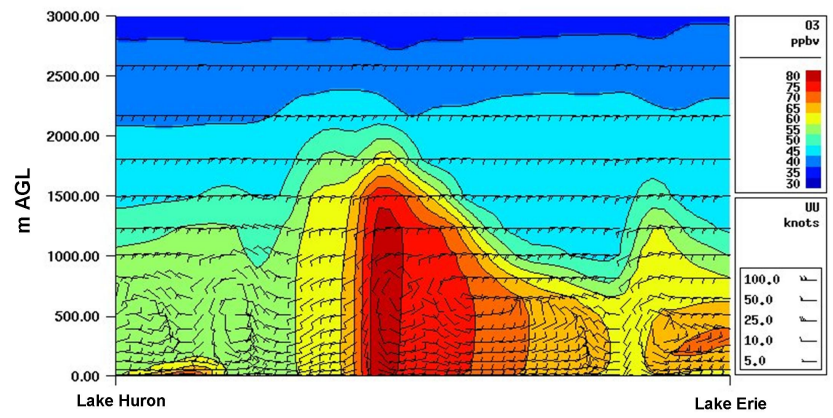

Fig. 14. Model-predicted ozone and wind fields, 8 July, 17:00 UT, Lake Huron to Lake Erie cross-section.

harder to discern; the average wind speed is sufficiently small to preclude plotting in several locations, probably indicating significant variability in the duration and direction of the surface divergence over the lakes by this time in the evening, over the averaging period. The figure shows that the lakebreeze circulation is a sufficiently robust feature that it affects the hourly average wind fields over the lakes.

\subsubsection{Hour-average ozone concentrations}

Time-averaged surface ozone concentrations for the same hours as Fig. 17 are shown in Fig. 18. The most significant high concentration ozone features are over Lake Erie, 

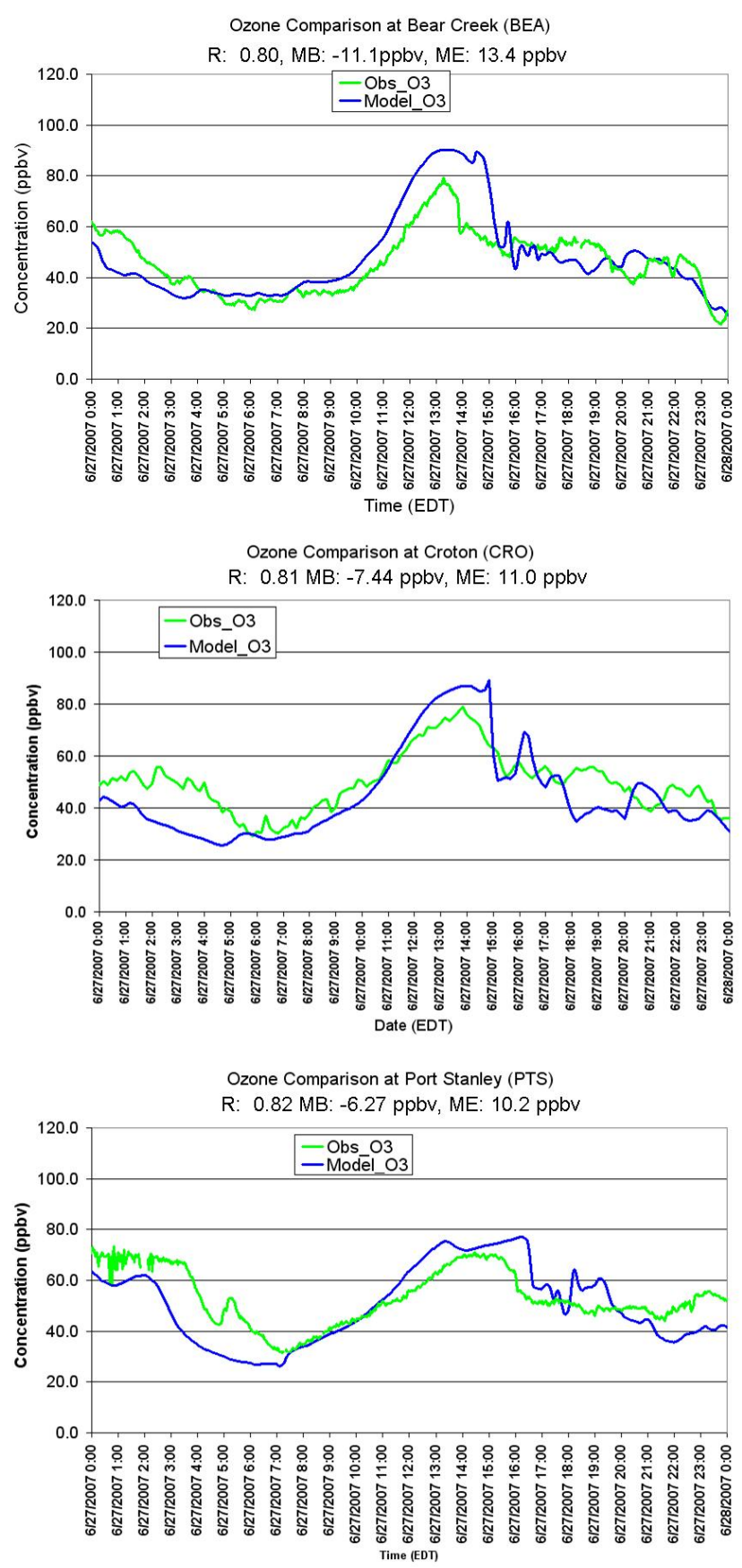

Fig. 15. Model-predicted surface ozone and wind fields for 27 June at (a) Croton, (b) Bear Creek, (c) Port Stanley. Statistical measures are for the entire measurement intensive, at each site.

and over the region shared by Detroit, Windsor, and Lake St. Clair (at 04:00 p.m., Fig. 18c). Figure 18c shows higher ozone on the US than on the Canadian side of Lake Erie this is due to differences in the emissions databases for the two countries (in Canada, shipping emissions are spatially allocated only along the main shipping lines, in the US, some shipping emissions are spread out over the south side of Lake

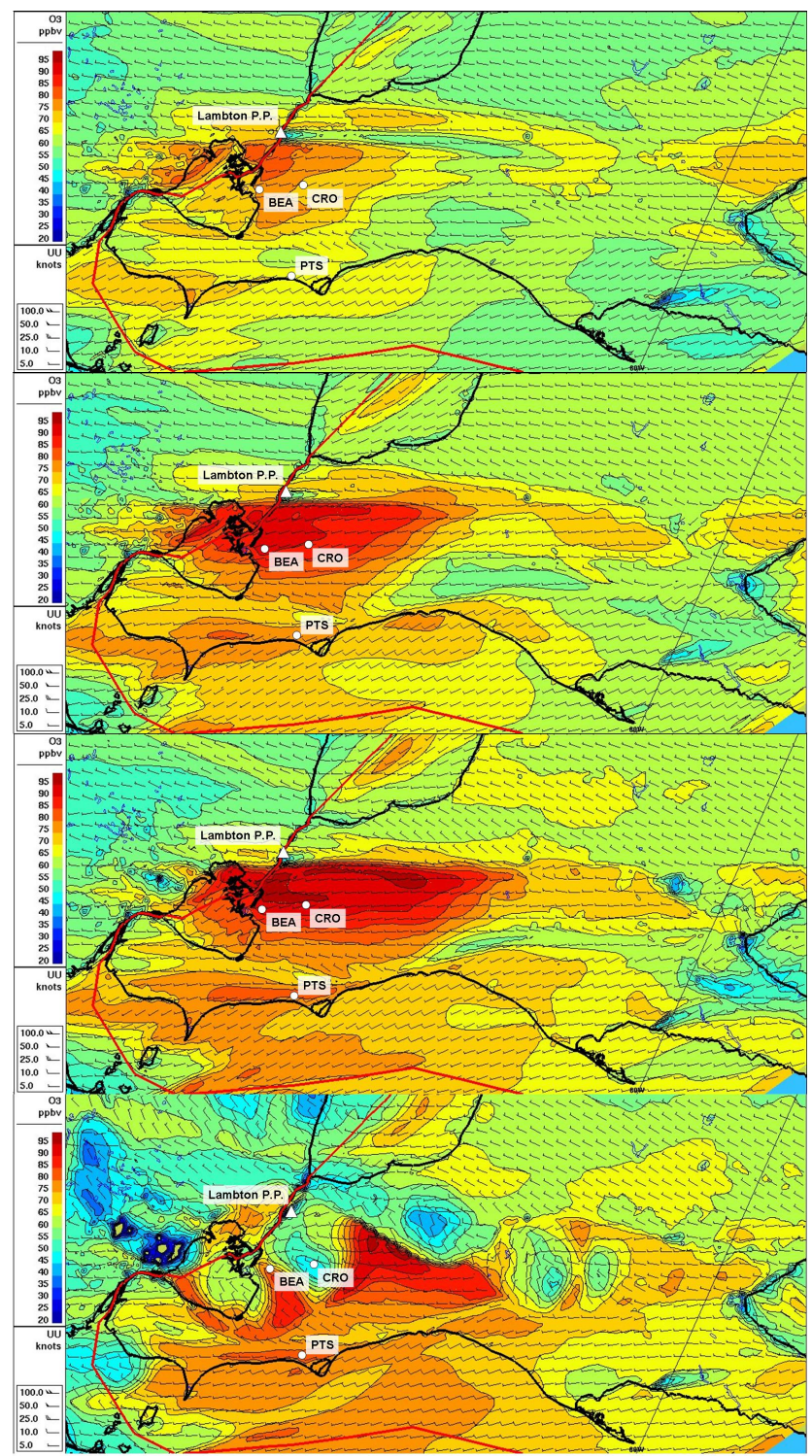

Fig. 16. Model-predicted surface ozone and wind fields for 27 June, (a) 16:00 UT (noon local time); (b) 17:00 UT (01:00 p.m.); (c) 18:00 UT (02:00 p.m.); (d) 19:00 UT (03:00 p.m.). CRO: Croton. BEA: Bear Creek. PTS: Port Stanley. Lambton P.P.: Lambton Power-Plant.

Erie). The large differences across the border suggest that accurate spatial allocation of shipping emissions is essential for forecasting ozone production over the Great Lakes, and that those emissions may have a significant effect on local ozone production.

The average Lake St. Clair surface ozone at 04:00 p.m. (Fig. 18c) is clearly enhanced within the region of the lakebreeze convergence line and surface outflow (Fig. 17c). It is difficult to distinguish any effect of the long convergence lines discussed earlier, probably due to their relatively short duration and highly time-varying positions, though some 


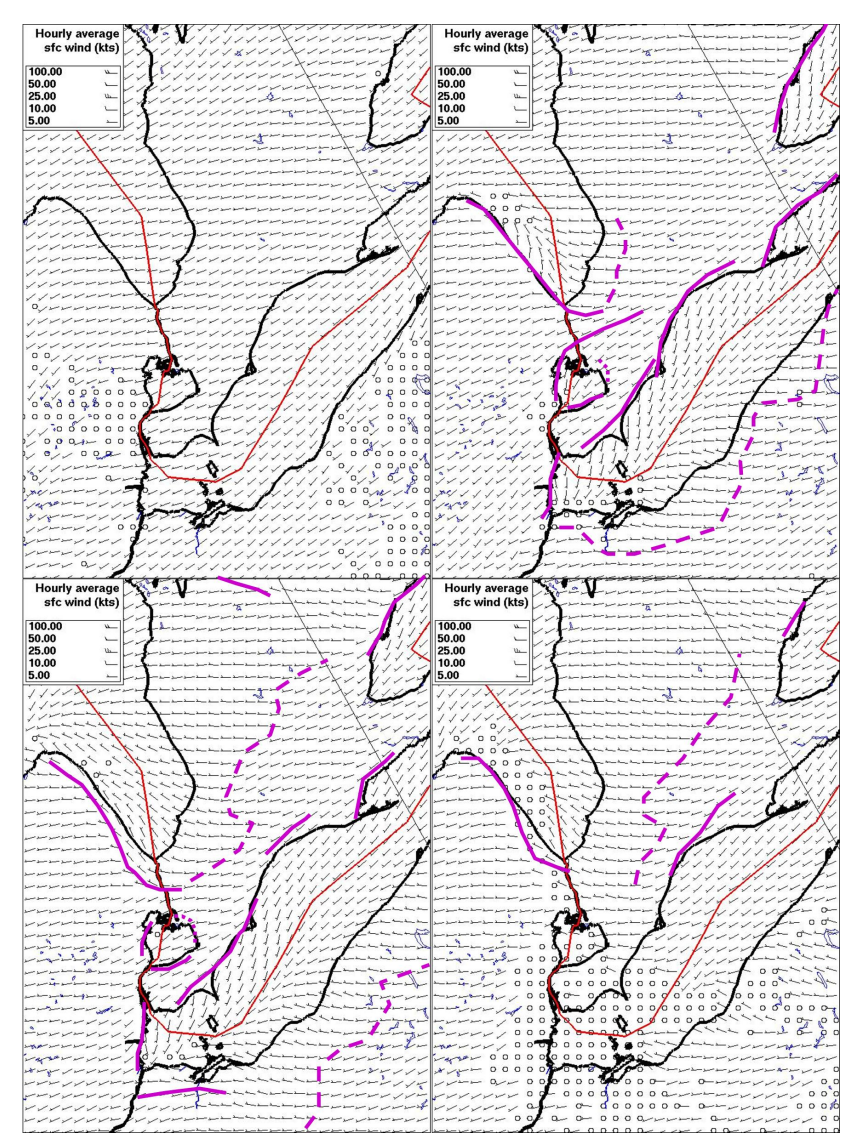

Fig. 17. 23-day average wind fields at (a) 12:00 UT, (b) 16:00 UT, (c) 20:00 UT, and (d) 00:00 UT; 08:00 a.m., 12:00 p.m., 04:00 p.m., and 08:00 p.m. local time, respectively. Convergence regions marked as solid mauve lines, boundary of divergence outflow regions marked with dashed mauve lines.

features do suggest their presence in the average. Figure 18c, $d$ shows enhanced ozone concentrations extending to the north-east from lake St. Clair (matching the convergence line of Fig. 17b and the Fig. 17c Lake Huron outflow location), and along the northern Lake Erie coastline and inland, matching the line of the convergence zone of Fig. 17c.

In order to examine the average ozone over Lakes St. Clair and Erie in more detail, the 23-day average 16:00 UT ozone concentrations at the surface over the lake, as well as the corresponding cross-sections of ozone concentration, ozone gas-phase production and loss and ozone transport are shown in Fig. 19 a-d. The size of each lake has a significant effect on the shape ozone production region in the vertical; over Lake St. Clair (left side of cross-sections, Fig. 19b), the region of enhanced average ozone extends to elevations of greater than $1500 \mathrm{~m}$, while the enhanced ozone over Lake Erie rises to no more than $250 \mathrm{~m}$ above the surface. Figure $19 \mathrm{c}$ shows that gas-phase photochemical production of ozone is the source of the high concentrations, but once again, the Lake St. Clair source (left side of the cross-section,

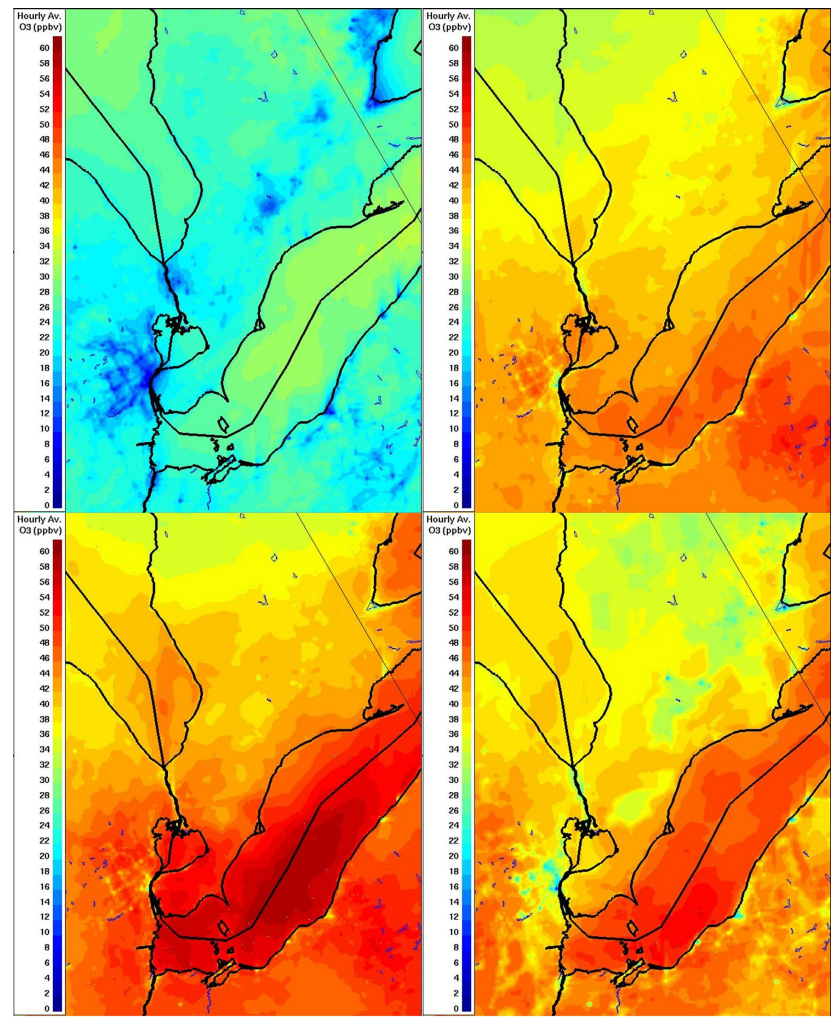

Fig. 18. 23-day average ozone concentration fields at (a) 12:00 UT, (b) 16:00 UT, (c) 20:00 UT, and (d) 00:00 UT; 08:00 a.m., 12:00 p.m., 04:00 p.m., and 08:00 p.m., respectively.

Fig. 19c) has a much greater vertical extent than that over Lake Erie (centre-right side of the cross-section, Fig. 19c). The average local gas-phase production rates are relatively high, up to 3 ppbv/hour. The transport pattern (Fig. 19d) differs between the two lakes. For Lake Erie, transport removes ozone in a thin layer near the surface, and a narrow region of ozone removal extending up to $1500 \mathrm{~m}$ is flanked by regions of positive ozone transport. The region of transport removal for Lake St. Clair is larger in vertical and horizontal extent, suggesting that at least some of the direction of transport is not in the plane of the cross-section. Deposition velocities of ozone are relatively low over water surfaces - the transport terms are thus dominated by diffusion and advection, as opposed to deposition fluxes removing ozone at the surface.

Figures 17 to 19 suggest that the local diurnal circulation associated with the two Lakes is sufficiently strong to be present in the 23-day average wind fields (17), that this circulation affects the ozone concentrations (18), that the Lakes are photochemical ozone production regions (19), the Lake St. Clair source being a dome roughly $1500 \mathrm{~m}$ in height and $\sim 30 \mathrm{~km}$ in diameter, and the Lake Erie source being relatively shallow ( $250 \mathrm{~m}$ altitude), but encompassing much of the S.W. side of the Lake. A 2-D cross-section of the simulated 3-D wind field through the 23-day averages across both 


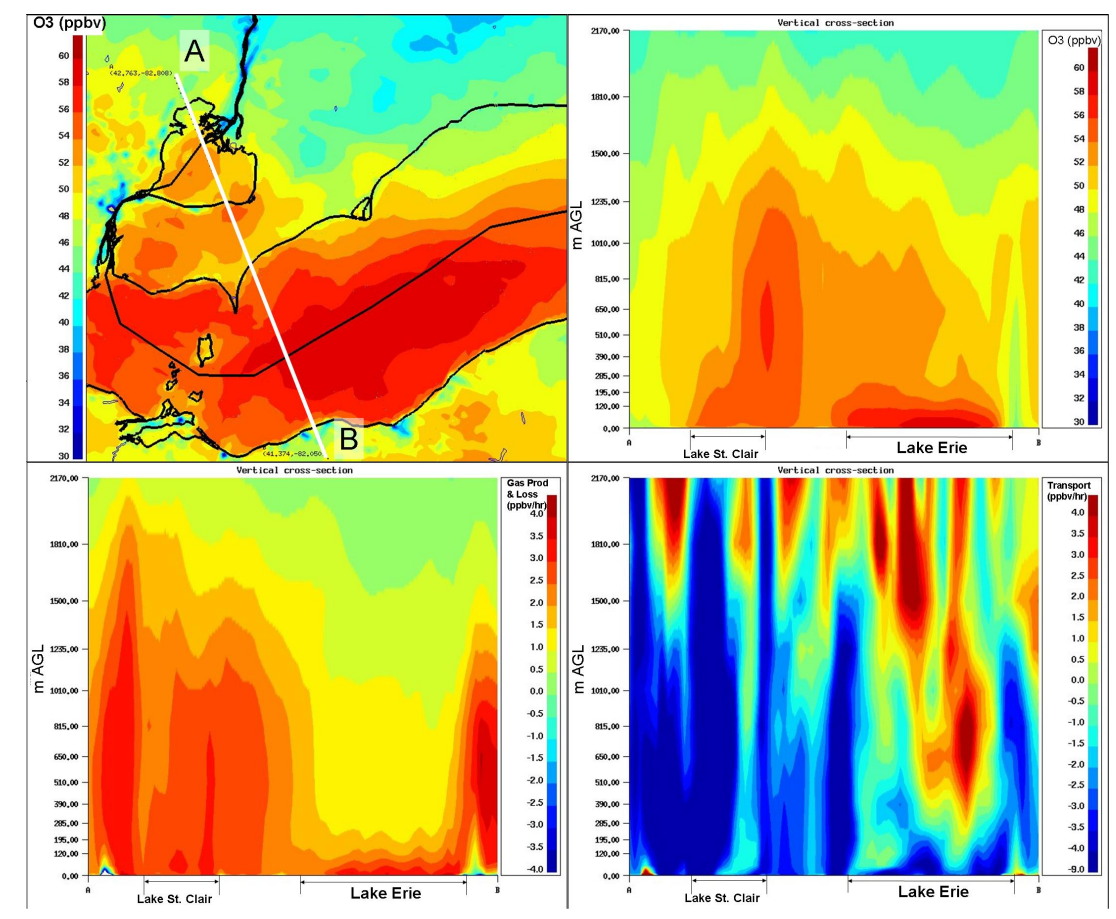

Fig. 19. 23-day average values at 20:00 UT (04:00 p.m. local time): (a) surface ozone over Lake St. Clair and Lake Erie, showing location of cross-section used for (b) ozone concentration, (c) ozone gas-phase production and loss, (d) ozone total transport.

lakes is shown in Fig. 20, and shows how differences in the circulation over each lake may give rise to their differences in the vertical distribution of gas-phase ozone production. At 08:00 a.m. (Fig. 20a), vertical winds are relatively light. By noon (Fig. 20b), a strong vertical circulation has developed. Updrafts over the north-west shore of Lake St. Clair, likely partially driven by the Detroit heat island ("A" to "B"), and downdrafts over the lake ("B" to "C"), suggest a helical circulation perpendicular to the main 23-day average synoptic flow (which is into the page in the cross-section; compare to Fig. 17c). If the synoptic wind is sufficiently low, this may allow a recirculation of pollutants over Lake St. Clair. A smaller helical pattern occurs aloft over Lake Erie, but the circulation over this lake implies a net subsidence near the surface. The relatively small size of Lake St. Clair (hence shorter transport times), along with the pairing of the Lake St. Clair downdraft with the Detroit updraft, increases the likelihood of recirculation of pollutants over this lake, relative to Lake Erie. By 04:00 p.m. (Fig. 20b), the Lake St. Clair vertical circulation has intensified and moved southwards, so that the updraft is now on the shore of the lake itself. The land between the two lakes has a well organized updraft region, due to daytime surface heating, and the convergence of the Lake St. Clair and Lake Erie lake breeze fronts. These vertical circulations explain the difference in the elevations of the ozone production regions noted above (Fig. 19), and similar features, including helical recirculation, have been noted in the literature (Levy et al., 2008).

\section{Sensitivity analysis of ozone and $\mathrm{HO}_{\mathrm{x}}$ formation to changes in precursor gases}

The sensitivity of ozone and $\mathrm{HO}_{\mathrm{x}}\left(=\mathrm{OH}+\mathrm{HO}_{2}\right)$ concentrations to changes in precursor gases were examined using 23day averages at 20:00 UT: five percent perturbations of the concentrations of each VOC, $\mathrm{NO}$ and $\mathrm{NO}_{2}$ at 20:00 UT were used to calculate finite difference sensitivities of ozone and $\mathrm{HO}_{\mathrm{x}}$ at 20:02 UT $\left(\frac{\Delta \mathrm{O}_{3}(\Delta t)}{\Delta \mathrm{VOC}(0)}, \frac{\Delta \mathrm{O}_{3}(\Delta t)}{\Delta \mathrm{NO}_{\mathrm{x}}(0)}\right)$, where $\Delta t=2 \mathrm{~min}$. The values of the change in final ozone concentration after two minutes of reaction time with respect to the change in initial total VOC and $\mathrm{NO}_{\mathrm{x}}$ are shown in Fig. 21. The urban areas, Lake St. Clair, the southern (USA) side of Lake Erie, and Lake Ontario are shown to be VOC limited: increases in VOC concentrations lead to ozone increases in these regions (Fig. 21a, red regions), while $\mathrm{NO}_{\mathrm{x}}$ increases lead to ozone destruction via titration (Fig. 21b, blue regions). Reductions in ozone concentrations in most of the study area could therefore be achieved through VOC emissions reductions. The highway network is clearly visible in both countries in Fig. 21, indicating ozone production has the greatest sensitivity to mobile emissions.

The role of $\mathrm{NO}_{\mathrm{x}}$ titration in ozone destruction is important in the context of the tendency towards increasingly negative surface ozone biases noted in Sect. 2.2, At lower horizontal resolutions, the $\mathrm{NO}_{\mathrm{x}}$ emitted from sub-grid-scale area sources (such as mobile, on-road sources) will de facto be dispersed over a larger horizontal grid-square than at higher 

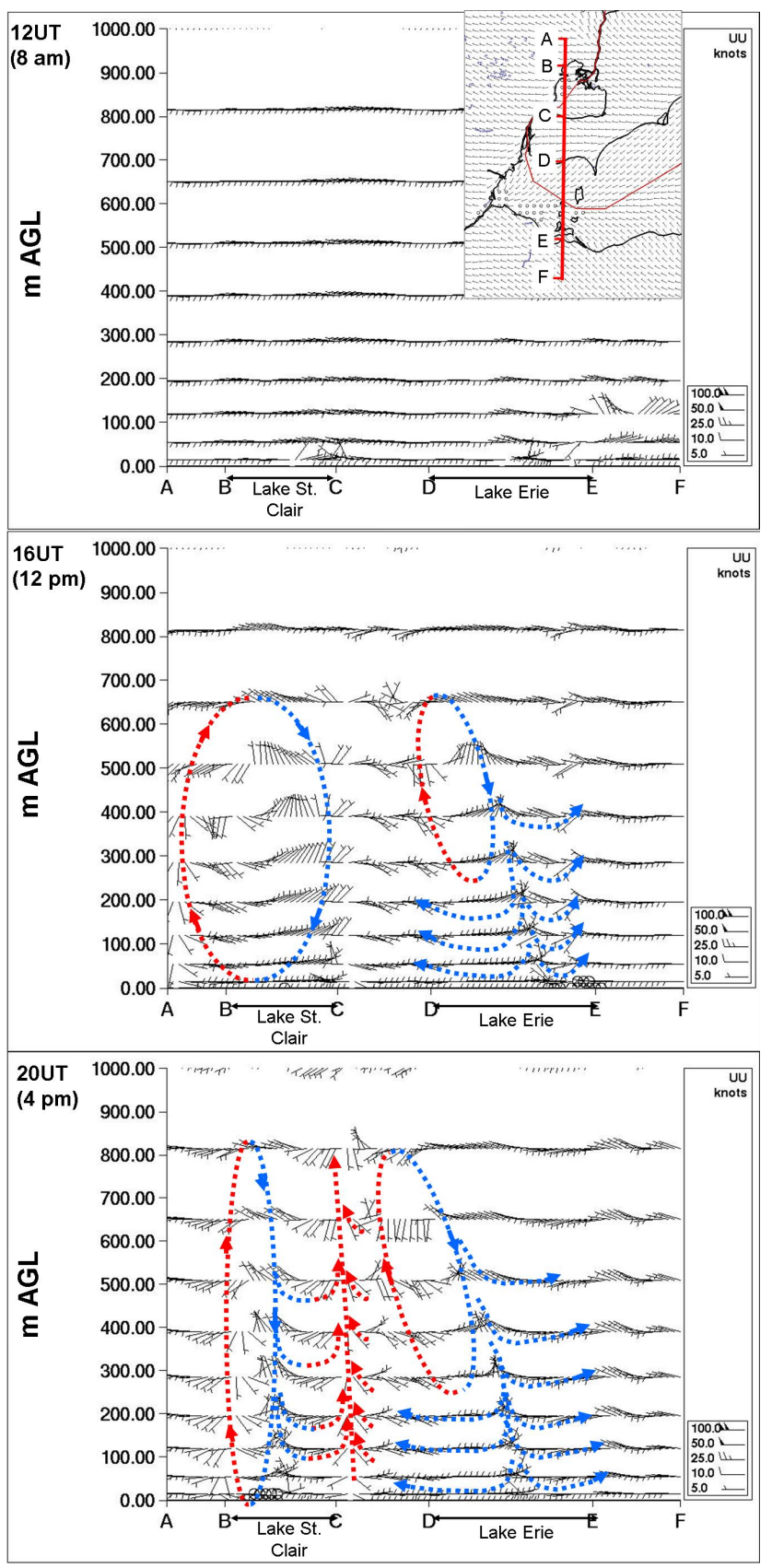

Fig. 20. Cross-section of 3-D wind fields across Lakes St. Clair and Erie at (a) 12:00 UT (08:00 a.m.), (b) 16:00 UT (12:00 noon), and (c) 20:00 UT (04:00 p.m.). Net upward motion streamlines are sketched in red, downward motion in blue. Inset: location of the cross-section, superimposed on 20:00 UT surface winds.

resolutions. The negative bias resulting at the highest resolution attempted here (see Table 2) implies either an overestimate in the surface $\mathrm{NO}_{\mathrm{x}}$ emissions source, or insufficient dispersion of the emitted $\mathrm{NO}_{\mathrm{x}}$ at higher resolution. In the latter hypothesis, the de facto numerical horizontal dispersion at lower resolutions masks or compensates for the absence of

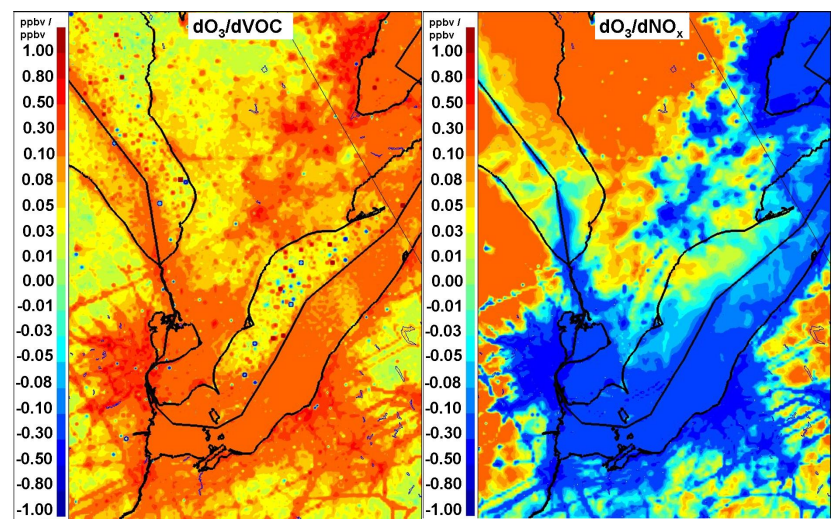

Fig. 21. Change in ozone after a two-minute timestep relative to change in (a) total VOC, and (b) $\mathrm{NO}_{\mathrm{x}}$ (ppbv/ppbv).

missing dispersive processes, a compensation that only becomes apparent at higher resolution.

The six VOCs for which ozone production has the greatest sensitivity are shown in Fig. 22. In decreasing order of importance, these VOCs are dialdehydes (Fig. 22e), $\mathrm{C}_{3+}$ alkenes (Fig. 22a), isoprene(Fig. 22c), methylglyoxal(Fig. 22e), xylene and higher carbon number aromatics (Fig. 22b) and cresols (Fig. 22f). In the ADOM-II gas-phase mechanism used in AURAMS (Stockwell and Lurmann, 1989), dialdehydes are the secondary products of toluene and xylene oxidation. The model suggests that ozone formation in the region is very sensitive to the overall oxidation of aromatics - and that this sensitivity increases substantially going from the initially emitted precursor to the secondary products in the oxidation chain. The aromatic emissions in this region are dominated by on-road mobile and ship emissions - suggesting that reductions in VOC emissions from these sources may help to reduce ozone concentrations in the area. Urban ozone in the region is also sensitive to the concentration of anthropogenic $\mathrm{C}_{3+}$ alkenes (Fig. 22a) and the largely biogenic isoprene (Fig. 22c). Earlier work (Stroud et al., 2008) noted that the initial reactivity of the emitted organics (that is, of the first species in the reaction chain) was reasonably well represented in the model in this region - here we show that the details of the subsequent reaction pathways may have a greater impact than the initial aromatic oxidation, and that the net reactivity of aromatics is the dominant factor in ozone production in this region.

The sensitivity of the model to $\mathrm{HO}_{\mathrm{x}}$ is of interest in that recent model mechanism intercomparisons suggest that many gas-phase mechanisms used in regional models may be biased low in their $\mathrm{HO}_{\mathrm{x}}$ predictions (Chen et al., 2010). The sensitivities of simulated $\mathrm{HO}_{\mathrm{x}}$ towards changes in $\mathrm{NO}_{\mathrm{x}}$ and VOCs are shown in Fig. 23. Outside of the urban areas, $\mathrm{HO}_{\mathrm{x}}$ concentrations are shown to increase with increasing VOC concentrations (Fig. 23a, green to red regions), while increasing $\mathrm{NO}_{\mathrm{x}}$ is shown to decrease $\mathrm{HO}_{\mathrm{x}}$ over most of the 


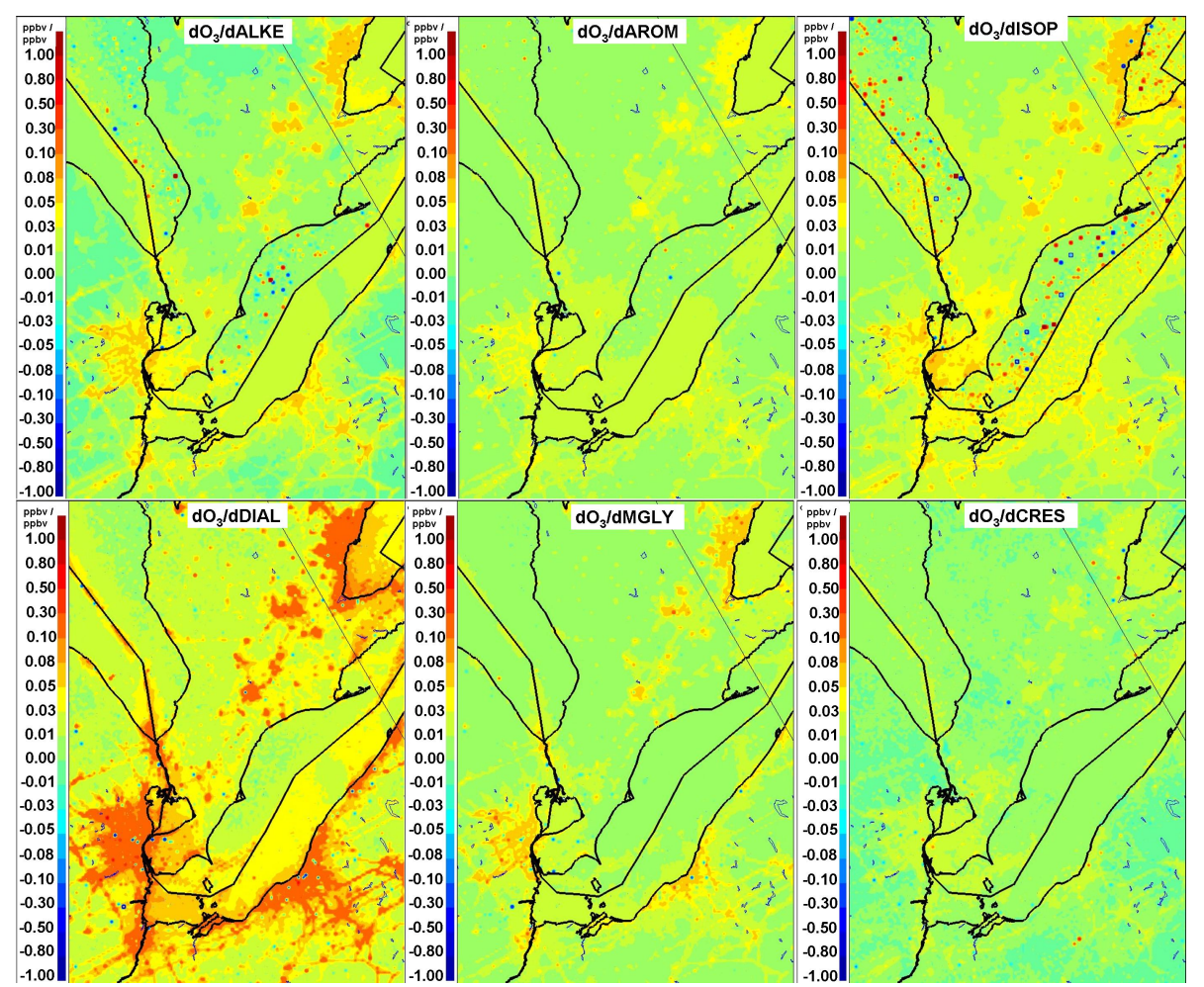

Fig. 22. Change in ozone after a two-minute timestep relative to change in (a) $\mathrm{C}_{3}+$ Alkenes, (b) Xylenes and higher carbon number aromatics, (c) Isoprene, (d) Dialdehydes, (e) Methylglyoxal, and (f) Cresols.

domain (Fig. 23b, blue regions), except over north-eastern Lake Huron and in the urban cores. Positive $\mathrm{NO}_{\mathrm{x}}$ biases noted earlier (Fig. 6) may thus lead to a negative bias in the predicted $\mathrm{HO}_{\mathrm{x}}$ levels. The two VOC species contributing the most to $\mathrm{HO}_{\mathrm{x}}$ production are dialdehydes and methylgloxal $(23 \mathrm{c}, \mathrm{d})$, probably due to the photolysis of these species, producing $\mathrm{HO}_{2}$. The dialdehyde sensitivities are highest far from the anthropogenic sources of the precursor aromatics - the long-range transport of the products of aromatic compounds are thus shown to have a significant impact on downwind $\mathrm{HO}_{\mathrm{x}}$ levels.

These results suggest that the details of the aromatic oxidation pathways will be quite important towards accurate ozone predictions and forecasting in this region, and will also have a significant impact on the model's ability to accurately pre$\operatorname{dict} \mathrm{HO}_{\mathrm{x}}$.

\section{Conclusions}

The simulations and comparisons with observations performed here suggest that ozone formation over the southern Great Lakes is significantly enhanced by local circulation and photochemical processing of precursors. Lakes Erie and St. Clair frequently act as photochemical production regions, with average enhancements up to 3 ppbv per hour by early afternoon. The size of the two lakes plays a crucial role in the manner in which ozone production is enhanced, with Lake St. Clair's small size and proximity to Detroit resulting in a "dome" of ozone production on the west side of the lake being released later in the afternoon, and Lake Erie's circulation resulting in subsidence over most of the lake water with precursor emissions being trapped there in the stable marine boundary layer. Ozone may be transported out of these source regions and the nearby urban areas in lake-breeze circulation convergence lines. These convergence lines result in elongated features of high concentration ozone, extending up to several hundred kilometres. Surface convergence of the local circulation carries the ozone and its precursors aloft and the synoptic wind thus carries the ozone much further downwind. The convergence lines are transient features lasting for a few hours on any given day, with their magnitude and direction being controlled by the synoptic scale winds. The photochemical production regions over the lakes are very robust features, sufficient to dominate 23-day averages of modelgenerated ozone concentrations, as well as its production and losses. The local nature of these features suggests that very local-scale emissions controls may have a significant impact on ozone concentrations in this region. Our results suggest that the location of local emission sources, relative to the average location of lake breeze surface convergence zones, may have a significant impact on ozone production in those zones (similar to the findings of Byun et al., 2007). A sensitivity 


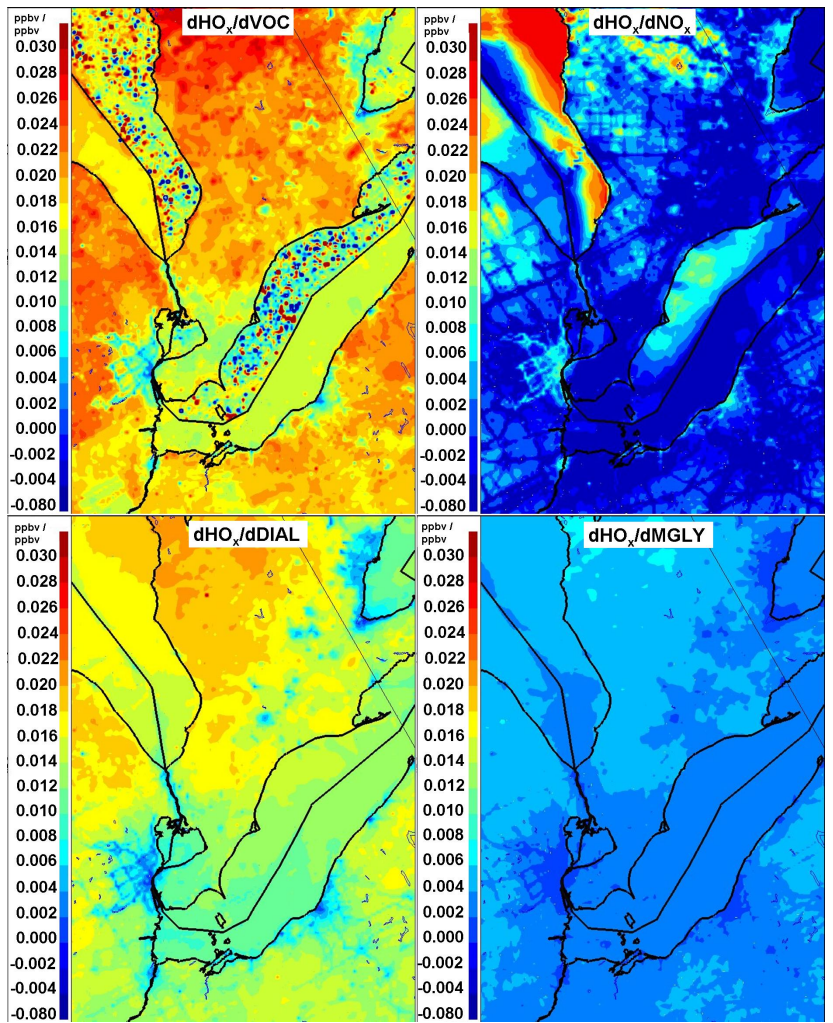

Fig. 23. Change in $\mathrm{HO}_{\mathrm{x}}$ after a two-minute timestep relative to change in (a) VOCs, (b) $\mathrm{NO}_{\mathrm{x}}$, (c) Dialdehydes, and (d) Methylglyoxal.

analysis of ozone chemistry suggests that most of the region is VOC-limited, and that the secondary oxidation pathways of the aromatic compounds play a key role in local ozone formation and in setting $\mathrm{HO}_{\mathrm{x}}$ concentrations.

While the above results have been statistically compared to observations, it should be noted that uncertainties exist in the gas-phase mechanisms used in regional models such as AURAMS. The effect of varying chemical mechanisms on ozone formation have been examined in previous work (Kuhn et al., 1998), with a 16\% RMS error for ozone associated with the choice of chemical mechanism (under polluted conditions), implying that the ozone analysis performed here should be relatively robust. Recent work with newly available $\mathrm{HO}_{\mathrm{x}}$ measurement technology (Chen et al., 2010) suggest that currently available gas-phase mechanisms may all underestimate $\mathrm{HO}_{\mathrm{x}}$. The authors in the latter study attribute this bias to measurement errors, the effects of unmeasured species, or mechanism errors, some of which are independent of the mechanism used. Both Kuhn et al. (1998) and Chen et al., (2010) suggest that predicted ozone concentrations become less sensitive to mechanism differences with increasing pollutant levels, and the latter study recommends that further work is needed to determine the cause of the known $\mathrm{HO}_{\mathrm{x}}$ deficiency. Here, we suggest that the secondary oxidation path- ways of aromatic compounds play a key role in setting $\mathrm{HO}_{\mathrm{x}}$ levels; improvements to these pathways are likely to increase the prediction accuracy of both ozone and $\mathrm{HO}_{\mathrm{x}}$. Similarly, our analysis suggests that improvements to the aromatic oxidation mechanisms which change the reactivity of the secondary products will have a significant impact on simulated ozone production. At the same time, we acknowledge that level of detail in emissions speciation for VOCs is a source of uncertainty in current regional models (cf. Makar et al., 2003).

The resolution-related statistics results have important implications for ozone forecasting in this region. Current air pollution model forecasts generated by the Canadian and US governments operate on 15 - and 12-km resolutions, respectively. These resolutions are insufficient to adequately resolve the lake-breeze circulations - while the high-resolution simulations performed here suggest that these same circulations may be responsible for enhancements of the regional ozone concentrations by $30 \mathrm{ppbv}$. The model results show a tendency towards increasingly negative ozone biases as the model is used at increasingly higher resolution: one possible implication of this finding (aside from the possibility of emissions overestimates) is insufficient dispersion in the model meteorology, that is masked by de facto numerical dispersion of emissions at lower resolution.

Acknowledgements. The authors would like to acknowledge the financial support of Environment Canada and the Ontario Ministry of the Environment for the BAQS-Met field study. We also gratefully acknowledge the assistance of the AIRNow program and its participating stakeholders.

Edited by: J. Abbatt

\section{References}

Anlauf, K. G., Lusis, M. A., Wiebe, H. A., and Stevens, R. D. S.: High ozone concentrations measured in the vicinity of Toronto, Canada, Atmos. Environ., 9, 1137-1139, 1975.

Atkinson, B. W.: Meso-scale Atmospheric Circulations, Academic Press, London, 495 pp., 1981.

Banta, R. M., Senff, C. J., Nielsen-Gammon, J., Darby, L. S., Ryerson, T. B., Alvarez, R. J., Sandberg, S. R., Williams, E. J., and Trainer, M.: A bad air day in Houston, B. Am. Meteorol. Soc., 86(5), 657-669, 2005.

Bastin, S. and Drobinski, P.: Sea-breeze-induced mass transport over complex terrain in south-eastern France: A case-study, Q. J. Roy. Meteorol. Soc., 132(615), 405-423, 2006.

Byun, D. W., Kim, S.-T., Kim, S.-B.: Evaluation of air quality models for the simulation of a high ozone episode in the Houston metropolitan area, Atmos. Environ., 41(4), 837-853, 2007.

CEP: Carolina Environmental Program, Sparse Matrix Operator Kernel Emission (SMOKE) modelling system, University of North Carolina, Carolina Environmental Programs, Chapel Hill, NC, available at: http://www.smoke-model.org/index.cfm, 2003.

Chen, S., Ren, X., Mao, J., Chen, Z., Brune, W. H., Lefer, B., Rappengluck, B., Flynn, J., Olson, J., and Crawford, J.: A compari- 
son of chemical mechanisms based on TRAMP-2006 field data, Atmos. Environ., 44, 4116-4125, 2010.

Cheng, F.-Y. and Byun, D. W.: Application of high resolution land use and land cover data for atmospheric modeling in the Houston-Galveston metropolitan area, Part I: Meteorological simulation results, Atmos. Environ., 42(33), 7795-7811, 2008.

Cheng, F.-Y., Kim, S., and Byun, D. W.: Application of high resolution land use and land cover data for atmospheric modeling in the Houston-Galveston Metropolitan area: Part II. Air quality simulation results, Atmos. Environ., 42(20), 4853-4869, 2008.

Cheng, W.-L.: Ozone distribution in coastal central Taiwan under sea-breeze conditions, Atmos. Environ., 36(21), 3445-3459, 2002.

Cho, S., Makar, P. A., Lee, W. S., Herage, T., Liggio, J., Li, S. M., Wiens, B., and Graham, L.: Evaluation of a unified regional airquality modeling system (AURAMS) using PrAIRie2005 field study data: The effects of emissions data accuracy on particle sulphate predictions, Atmos. Environ., 43, 1864-1877, 2009.

Côté, J., Gravel, S., Méthot, A., Patoine, A., Roch, M., and Staniforth, A.: The operational CMC-MRB Global Environmental Multiscale (GEM) model. Part 1: Design considerations and formulation, Mon. Weather Rev., 126, 1373-1395, 1998.

Darby, L. S.: Cluster analysis of surface winds in Houston, Texas, and the impact of wind patterns on ozone, J. Appl. Meteorol., 44(12), 1788-1806, 2005.

Darby, L. S., McKeen, S. A., Senff, C. J., White, A. B., Banta, R. M., Post, M. J., Brewer, W. A., Marchbanks, R., Alvarez II, R. J., Peckham, S. E., Mao, H., and Talbot, R.: Ozone differences between near-coastal and offshore sites in New England: Role of meteorology, J. Geophys. Res. Atmos., 112(16), D16S91, doi:10.1029/2007JD008446, 2007.

Drobinski, P., Saïd, F., Ancellet, G., Arteta, J., Augustin, P., Bastin, P., Brut, A., Caccia, J. L., Campistron, B., Cautenet, S., Colette, A., Coll, I., Corsmeier, U., Cros, B., Dabas, A., Delbarre, H., Dufour, A., Durand, P., Guénard, V., Hasel, M., Kalthoff, N., Kottmeier, C., Lasry, F., Lemonsu, A., Lohou, F., Masson, V., Menut, L., Moppert, C., Peuch, V. H., Puygrenier, V., Reitebuch, O., and Vautard, R. 2007. Regional transport and dilution during high-pollution episodes in southern France: Summary of findings from the Field Experiment to Constraint Models of Atmospheric Pollution and Emissions Transport (ESCOMPTE), J. Geophys. Res. Atmos., 112(13), D13105, doi:10.1029/2006JD007494, 2007.

Gipson, G. L.: Chapter 16, Process Analysis, in: Science Algorithms of the EPA Models-3 Community Multiscale Air Quality (CMAQ) Modeling System, edited by: Byun, D. W. and Ching, J. K. S., United States Environmental Protection Agency, Office of Research and Development, Washington, DC, EPA/600/R99/030, 512 pp., 1999.

Gong, W., Dastoor, A. P. , Bouchet, V. S., Gong, S., Makar, P. A., Moran, M. D., Pabla, B., Ménard, S., Crevier, L.-P., Cousineau, S., and Venkatesh, S.: Cloud processing of gases and aerosols in a regional air quality model (AURAMS), Atmos. Res., 82, 248$275,2006$.

Hastie, D. R., Narayan, J., Schiller, C., Niki, H., Shepson, P. B., Sills, D. M. L., Taylor, P. A., Moroz, Wm. J., Drummond, J. W., Reid, N., Taylor, R., Roussel, P. B., and Melo, O. T.: Observational evidence for the impact of lake breeze circulation on ozone concentrations in southern Ontario, Atmos. Environ., 33,
323-335, 1999.

Hayden, K., Sills, D. M. L., Li, S., Brook, J., Anlauf, K. G., O'Brien, J. and Sharma, S., 2010. The impact of lake breezes on trace gases and particles during the Border Air Quality and Meteorology Study (BAQS-Met), to be submitted to Atmos. Chem. Phys. Discuss., 2010.

He, H., Tarasick, D. W., Hocking, W. K., Carey-Smith, T. K., Rochon, Y., Zhang, J., Makar, P. A., Osman, M., Brook, J., Moran, M., Jones, D., Mihele, C., Wei, J. C., Osterman, G., Argall, P. S., McConnell, J., and Bourqui, M. S.: Transport analysis of ozone enhancement in Southern Ontario during BAQS-Met, Atmos. Chem. Phys. Discuss., 10, 15559-15593, doi:10.5194/acpd-1015559-2010, 2010.

Houyoux, M. R., Vukovich, J. M., Coats Jr., C. J., and Wheeler, N. J. M.: Emission inventory development and processing for the Seasonal Model for Regional Air Quality (SMRAQ) project, J. Geophys. Res., 105, 9079-9090, 2000.

Jang, J.-C. C., Jeffries, H. E., and Tonnesen, S.: Sensitivity of ozone to model grid resolution - II. Detailed process analysis for ozone chemistry, Atmos. Environ., 29, 3101-3114, 1995.

Jeffries, H. E. and Tonnesen, S.: A comparison of two photochemical reaction mechanisms using mass balance and process analysis, Atmos. Environ., 28, 2991-3003, 1994.

Kuhn, M., Builtjes, P. J. H., Poppe, D. Simpson, D., Stockwell, W. R., Andersson-Skoeld, Y., Baart, A., Das, M., Fiedler, F., Hov, O., Kirchner, F., Makar, P. A., Milford, J. B., Roemer, M. G. M., Ruhnke, R., Strand, A., Vogel, B., and Vogel, H.: Intercomparison of the Gas-Phase Chemistry in Several Chemistry and Transport Models, Atmos. Environ., 32, 693-709, 1998.

Laird, N. F., Kristovich, D. A. R., Liang, X.-Z., Arritt, R. W., and Labas, K.: Lake Michigan lake breezes: climatology, local forcing, and synoptic environment, J. Appl. Meteorol., 40(3), 409424, 2001.

Lasry, F., Coll, I., and Buisson, E.: An insight into the formation of severe ozone episodes: Modeling the 21/03/01 event in the ESCOMPTE region, Atmos. Res., 74(1-4), 191-215, 2005.

Lemonsu, A., Bastin, S., Masson, V., and Drobinski, P.: Vertical structure of the urban boundary layer over Marseille under sea-breeze conditions, Bound.-Lay. Meteorol., 118(3), 477-501, 2006a.

Lemonsu, A., Pigeon, G., Masson, V., and Moppert, C.: Sea-town interactions over Marseille: 3-D urban boundary layer and thermodynamic fields near the surface, Theor. Appl. Climatol., 84(13), 171-178, $2006 \mathrm{~b}$.

Levy, I., Dayan, U., and Mahrer, Y.: A five-year study of coastal recirculation and its effect on air pollutants over the East Mediterranean region, J. Geophys. Res. Atmos., 113(16), D16121, doi:10.1029/2007JD009529, 2008.

Levy, I., Makar, P. A., Sills, D., Zhang, J., Hayden, K. L., Mihele, C., Narayan, J., Moran, M. D., Sjostedt, S., and Brook, J.: Unraveling the complex local-scale flows influencing ozone patterns in the southern Great Lakes of North America, Atmos. Chem. Phys., 10, 10895-10915, doi:10.5194/acp-10-10895-2010, 2010.

Li, S. M.: A concerted effort to understand the ambient particulate matter in the Lower Fraser Valley: The Pacific 2001 Air Quality Study, Atmos. Environ., 38(34), 5719-5731, 2004.

Lu, R. and Turco, R. P.: Air Pollutant Transport in a Coastal Environment - II. Three-Dimensional Simulations over Los Angeles Basin., Atmos.-Environ., 29, 1499-1518, 1995. 
Lyons, W. A. and Cole, H. S.: Fumigation and Plume Trapping on the Shores of Lake Michigan During Stable Onshore Flow, J. Appl. Meteorol., 12, 494-510, 1973.

Lyons, W. A. and Cole, H. S.: Photochemical Oxidant Transport: Mesoscale Lake Breeze and Synoptic-Scale Aspects, J. Appl. Meteorol., 15, 733-743, 1976.

Lyons, W. A. and Olsson, L. E.: Detailed Mesometeorological Studies of Air Pollution Dispersion in the Chicago Lake Breeze, Mon. Weather Rev., 101, 387-403, 1973.

Lyons W. A., Keen, C. S., and Schuh, J. A.: Modeling mesoseale diffusion and transport processes for releases within coastal zones during land/sea breezes, US Nuclear Regulatory Commission, NUREG/CR-3542, Washington, DC, 202 pp., 1983.

Lyons, W. A., Pielke, R. A., Tremback, C. J., Walko, R. L., Moon, D. A., and Keen, C. S.: Modeling Impacts of Mesoscale Vertical Motions upon Coastal Zone Air Pollution Dispersion, Atmos.Environ., 29, 283-301, 1995.

Makar, P. A., Moran, M. D., Schultz, M. T., and Taylor, A.: Speciation of volatile organic compound emissions for regional air quality modeling of particulate matter and ozone, J. Geophys. Res., 108(D2), 4041, doi:1029/2001JD000797, 2003.

Makar, P. A., Gravel, S., Chirkov, V., Strawbridge, K. B., Froude, F., Arnold, J., and Brook, J.: Heat flux, urban properties, and regional weather, Atmos. Environ., 40, 2750-2766, 2006.

Makar, P. A., Moran, M. D., Zheng, Q., Cousineau, S., Sassi, M., Duhamel, A., Besner, M., Davignon, D., Crevier, L.-P., and Bouchet, V. S.: Modelling the impacts of ammonia emissions reductions on North American air quality, Atmos. Chem. Phys., 9, 7183-7212, doi:10.5194/acp-9-7183-2009, 2009.

Makar, P. A., Gong, W., Mooney, C., Zhang, J., Davignon, D., Samaali, M., Moran, M. D., He, H., Tarasick, D. W., Sills, D., and Chen, J.: Dynamic adjustment of climatological ozone boundary conditions for air-quality forecasts, Atmos. Chem. Phys., 10, 8997-9015, doi:10.5194/acp-10-8997-2010, 2010.

Marchuk, G. I.: Methods of numerical mathematics, SpringerVerlag, New York, 316 pp., 1975.

Mestayer, P. G., Durand, P., Augustin, P., Bastin, S., Bonnefond, J.-M., Bénech, B., Campistron, B., Coppalle, A., Delbarre, H., Dousset, B., Drobinski, P., Druilhet, A., Fréjafon, E., Grimmon, C. S. B., Groleau, D., Irvine, M., Kergomard, C., Kermadi, S., Lagouarde, J.-P., Lemonsu, A., Lohou, F., Long, N., Masson, V., Moppert, C., Noilhan, J., Offerle, B., Oke, T. R., Pigeon, G., Puygrenier, V., Roberts, S., Rosant, J.-M., Saïd, F., Salmond, J., Talbaut, M., and Voogt, J.: The Urban Boundary-Layer Field Campaign in Marseille (UBL/CLU-ESCOMPTE): Set-Up and First Results, Bound.-Lay. Meteorol., 114, 315-365, 2005.

Millán, M. M., Salvador, R., Mantilla, E., and Kallos, G.: Photooxidant dynamics in the Mediterranean basin in summer: Results from European research projects, J. Geophys. Res., 102, 88118823, 1997.
Millán, M. M., Mantilla, E., Salvador, R., Carratalá, A., Sanz, M. J., Alonso, L., Gangoiti, G., and Navazo, M.: Ozone cycles in the western Mediterranean basin: interpretation of monitoring data in complex coastal terrain, J. Applied Meteorol., 39, 487-508, 2000.

Mukammal, E. I.: Ozone as a cause of tobacco injury, Agr. Meteorol., 2, 145-165, 1965.

Mukammal, E. I., Neumann, H. H., and Gillespie, T. J.: Meteorological Conditions Associated with Ozone in Southwestern Ontario, Canada, Atmos. Environ., 16, 2095-2106, 1982.

Mukammal, E. I., Neumann, H. H., and Nichols, T. R.: Some Features of the Ozone Climatology of Ontario, Canada and Possible Contributions of Stratospheric Ozone to Surface Concentrations, Arch. Met. Geoph. Biocl., 34, 179-211, 1985.

Pirovano, G., Coll, I., Bedogni, M., Alessandrini, S., Costa, M. P., Gabusi, V., Lasry, F., Menut, L., and Vautard, R.: On the influence of meteorological input on photochemical modelling of a severe episode over a coastal area, Atmos. Environ., 41(30), 6445-6464, 2007.

Puygrenier, V., Lohou, F., Campistron, B., Saïd, F., Pigeon, G., Benech, B., and Serça, D.: Investigation on the fine structure of sea-breeze during ESCOMPTE experiment, Atmos. Res., 74(14), 329-353, 2005.

Rappenglück, B., Perna, R., Zhong, S., and Morris, G. A.: An analysis of the vertical structure of the atmosphere and the upperlevel meteorology and their impact on surface ozone levels in Houston, Texas, J. Geophys. Res. Atmos., 113(17), D17315, doi:10.1029/2007JD009745, 2008.

Sills, D., Brook, J., Taylor, P., Zhang, J., Levy, I., Makar, P. A., and Hayden, K.: Lake breezes in the southern Great Lakes and their influence during BAQS-Met2007, to be submitted to Atmos. Chem. Phys. Discuss., 2010.

Smyth, S. C., Jiang, W., Roth, H., Moran, M. D., Makar, P. A., Yang, F., Bouchet, V. S., and Landry, H.: A comparative performance evaluation of the AURAMS and CMAQ air quality modelling systems, Atmos. Environ., 43, 1059-1070, 2009.

Stockwell, W. R and Lurmann, F. W.: Intercomparison of the ADOM and RADM Gas-Phase Chemical Mechanisms, Topical Report, Electric Power Research Institute, Palo Alto, Ca., USA, 259 pp., 1989.

Stroud, C. A., Morneau, G., Makar, P. A., Moran, M. D., Gong, W., Pabla, B., Zhang, J., Bouchet, V. S., Fox, D., Venkatesh, S., Wang, D., and Dann, T.: OH-reactivity of volatile organic compounds at urban and rural sites across Canada: Evaluation of air quality model predictions using speciated VOC measurements, Atmos. Environ., 42(33), 7746-7756, 2008.

Stull, R. B.: An Introduction to Boundary Layer Meteorology, Kluwer Academic Publishers, Boston, 666 pp., 1988.

Yap, D., Ning, D. T., and Dong, W.: An assessment of source contributions to the ozone concentrations in southern Ontario, 19791985, Atmos. Environ., 22, 1161-1168, 1988. 